\title{
The Social Dimension of Regional Integration in ECOWAS
}

\author{
Working Paper No. 49
}

\section{René Robert}

\section{Policy Integration Department International Labour Office Geneva}

December 2004 
Copyright (C) International Labour Organization 2005

Publications of the International Labour Office enjoy copyright under Protocol 2 of the Universal Copyright Convention. Nevertheless, short excerpts from them may be reproduced without authorization, on condition that the source is indicated. For rights of reproduction or translation, application should be made to the Publications Bureau (Rights and Permissions), International Labour Office, CH-1211 Geneva 22, Switzerland. The International Labour Office welcomes such applications.

Libraries, institutions and other users registered in the United Kingdom with the Copyright Licensing Agency, 90 Tottenham Court Road, London W1T 4LP [Fax: (+44) (0)20 7631 5500; email: cla@cla.co.uk], in the United States with the Copyright Clearance Center, 222 Rosewood Drive, Danvers, MA 01923 [Fax: (+1) (978) 750 4470; email: info@copyright.com] or in other countries with associated Reproduction Rights Organizations, may make photocopies in accordance with the licences issued to them for this purpose.

ISBN 92-2-116751-8 (printed version)

ISBN 92-2-116752-6 (web version)

First published 2005

Cover:

The designations employed in ILO publications, which are in conformity with United Nations practice, and the presentation of material therein do not imply the expression of any opinion whatsoever on the part of the International Labour Office concerning the legal status of any country, area or territory or of its authorities, or concerning the delimitation of its frontiers.

The responsibility for opinions expressed in signed articles, studies and other contributions rests solely with their authors, and publication does not constitute an endorsement by the International Labour Office of the opinions expressed in them.

Reference to names of firms and commercial products and processes does not imply their endorsement by the International Labour Office, and any failure to mention a particular firm, commercial product or process is not a sign of disapproval.

ILO publications can be obtained through major booksellers or ILO local offices in many countries, or direct from ILO Publications, International Labour Office, CH-1211 Geneva 22, Switzerland. Catalogues or lists of new publications are available free of charge from the above address, or by email: pubvente@ilo.org

Visit our website: www.ilo.org/publns 


\section{The Social Dimension of Regional Integration in ECOWAS}

\section{Contents}

Preface

List of Acronyms ..................................................................................................................................... vii

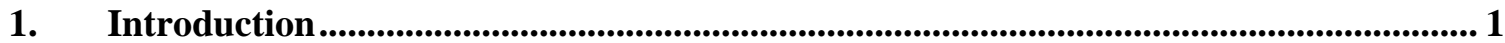

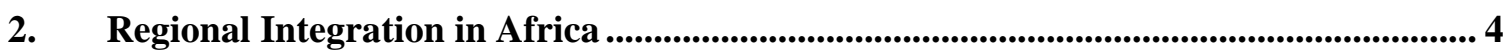

3. Economic Community of West African States (ECOWAS) ........................................ 5

3.1 Constraints on West African Integration - WAEMU and Institutional Overlap ......... 6

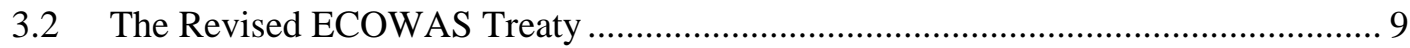

4. Regional Institutions and the Social Dimension of ECOWAS ........................................ 11

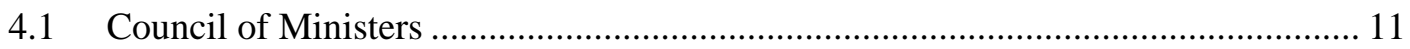

4.2. Human Resources, Information, Social and Cultural Affairs Commission ................ 12

4.3. ECOWAS Community Court of Justice ................................................................... 12

4.4 ECOWAS Community Parliament ........................................................................... 14

5. ECOWAS, Employment Law and Workers' Rights............................................................ 15

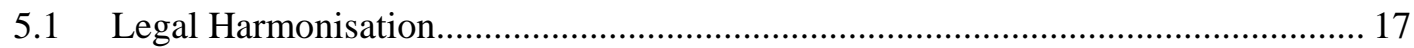

5.2. Organization for the Harmonisation of Business Law in Africa (OHADA) ............. 18

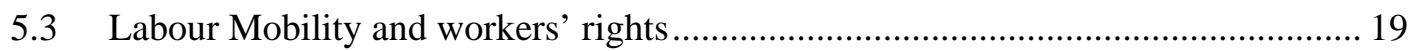

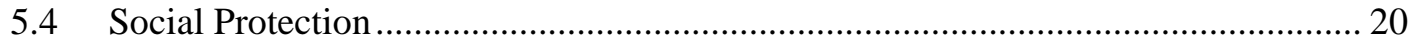

6. ECOWAS and Development Frameworks ....................................................................... 22

6.1 Towards a Regional Poverty Reduction Strategy Paper (PRSP) .............................. 22

6.2. The New Partnership for Africa's Development (NEPAD) .................................... 23

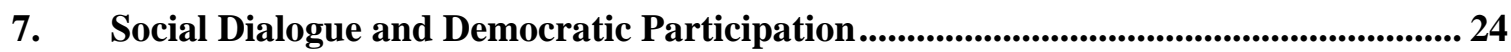

7.1 The Legal Framework........................................................................................... 24

7.2 Organization of Trade Unions in West Africa (OTUWA) ........................................ 26

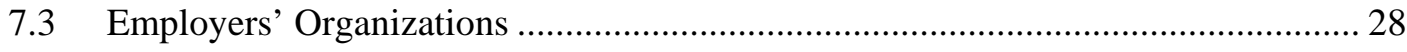

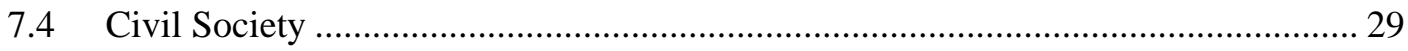

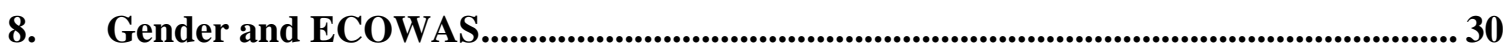

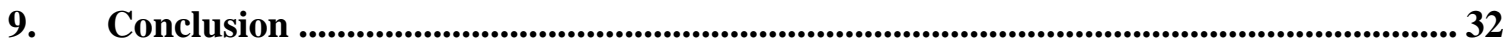


Annex 1 - Chapter XI of the Revised Treaty of ECOWAS....................................................... 35

Annex 2 - Regional Economic Communities in Africa ........................................................... 39

Annex 3 - ECOWAS and the ILO Fundamental Conventions ................................................... 41

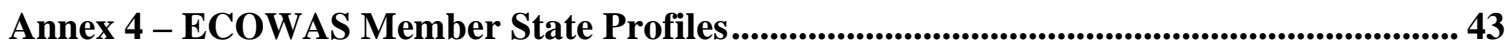


Peace and unity and social justice everywhere,

Cultural integration and liberty we declare!

Women and youth, all shall maintain our future bright, in health;

Human and natural resources shall sustain our wealth.

- Excerpt from ECOWAS anthem 


\section{Preface}

As the World Commission on the Social Dimension of Globalization noted in its report, A fair globalization: Creating opportunities for all (ILO, Geneva, 2004), regional economic integration can be a stepping stone to a fairer globalization. Yet each regional economic arrangement has its own purpose, legal framework, institutional set-up, history and trajectory. A better understanding of these factors is essential to identifying how regional economic integration arrangements can indeed pursue their own paths, at their own pace, towards a fairer globalization for the people within them.

René Robert's study of the Economic Community of West African States (ECOWAS) makes a significant contribution to such understanding. As he notes, regional integration is as much about governance as it is about trade liberalization and its social impact. Beyond describing its structures and the main areas of accomplishment to date, the author places ECOWAS in a broader setting. Thus he looks at ECOWAS in relation to regional economic integration on the African continent, with a particular focus on two other prominent regional initiatives in West Africa: the West African Economic and Monetary Union (WAEMU) and the Organization for the Harmonisation of Business Law in Africa (OHADA). Against this background, the author examines ECOWAS in the context of labour law harmonisation, poverty reduction strategies for development, gender empowerment and democratic participation. In so doing, he points out both the challenges and the opportunities.

His observations and conclusions highlight the avenues open to African regional economic communities to strengthen socio-economic development. Foremost among these is reinforcing social dialogue and the social partners for their effective engagement. The author makes suggestions as to how the ILO and other institutions could facilitate this process in ECOWAS, which is politically open to it. Just as cooperation on security issues has deepened within ECOWAS over time, so too could the social dimension of integration evolve in this sub-region - all the moreso given the link between social justice within societies and peace and security within sub-regions.

René Robert is an attorney and member of the Law Society of Upper Canada. Previously, he worked at the Commission for Labour Cooperation in Washington D.C. where he researched cross-border occupational health and safety in the context of the North American Free Trade Agreement. He wrote this paper while under contract with the International Labour Office. A visit to the ILO by a delegation from the ECOWAS Secretariat in November 2004 provided an opportunity to receive informal feedback on an earlier draft of this paper.

The author's insights on the social dimension of regional economic integration go well beyond ECOWAS. They provide food for thought about the potential of such processes for a more inclusive globalization in other contexts as well. Comments on this Working Paper, which expresses the author's views and is intended to stimulate discussion, are most welcome.

\section{Anne Trebilcock \\ Deputy Director \\ Policy Integration Department \\ International Labour Office}

December 2004 


\section{List of Acronyms}

$\begin{array}{ll}\text { ACP } & \text { African, Caribbean and Pacific } \\ \text { ADB } & \text { African Development Bank } \\ \text { AEC } & \text { African Economic Community } \\ \text { AGOA } & \text { African Growth and Opportunity Act } \\ \text { ARIA } & \text { Assessing Regional Integration in Africa } \\ \text { ASEAN } & \text { Association of South East Asian Nations } \\ \text { AU } & \text { African Union } \\ \text { CSO } & \text { Civil Society Organization } \\ \text { EAC } & \text { East African Community } \\ \text { ECA } & \text { United Nations Economic Commission for Africa } \\ \text { ECOMOG } & \text { ECOWAS Monitoring Group } \\ \text { ECOWAS } & \text { Economic Community of West African States } \\ \text { EU } & \text { European Union } \\ \text { HR } & \text { Human Resources } \\ \text { ILO } & \text { International Labour Organization } \\ \text { MERCOSUR } & \text { Southern Cone Common Market } \\ \text { MOU } & \text { Memorandum of Understanding } \\ \text { NAALC } & \text { North American Agreement on Labor Cooperation } \\ \text { NAFTA } & \text { North American Free Trade Agreement } \\ \text { NEPAD } & \text { New Partnership for Africa's Development } \\ \text { NGO } & \text { Non-governmental Organization } \\ \text { OAU } & \text { Organization of African Unity } \\ \text { OECD } & \text { Organization for Economic Cooperation and Development } \\ \text { OHADA } & \text { Organization for the Harmonisation of Business Law in } \\ & \text { Africa } \\ \text { OTUWA } & \text { Organization of Trade Unions of West Africa } \\ \text { PRSP } & \text { Poverty Reduction Strategy Paper } \\ \text { REC } & \text { Regional Economic Community } \\ \text { SADC } & \text { Southern African Development Community } \\ \text { TLS } & \text { Trade Liberalisation Scheme } \\ \text { UNCTAD } & \text { United Nations Conference on Trade and Development } \\ \text { USTR } & \text { United States Trade Representative } \\ \text { WACSOF } & \text { West African Civil Society Forum } \\ \text { WAEMU } & \text { West African Economic and Monetary Union } \\ \text { WAEN } & \text { West African Enterprise Network } \\ \text { WAWA } & \text { West African Women's Association } \\ \text { WTO } & \text { World Trade Organization } \\ & \end{array}$




\section{Introduction}

This paper intends, through an examination of ECOWAS, to assess the obstacles and possibilities of incorporating social concerns relating to labour and employment into regional policies and institutions, and what opportunities there are in this area for improvement as well as greater cooperation with the ILO.

Regional integration (RI) is typically associated, though is not limited to, the objectives of increased trade and stronger economic linkages between countries. Yet as the recent report of the World Commission on the Social Dimension of Globalization emphasizes, RI can and should play a greater role in addressing issues such as democratic participation, respect for basic rights, education, social security and poverty reduction - in essence, the social dimension. To better understand what this social dimension looks like in practice, it is useful to consider regional integration from two different, though complementary, perspectives. The first, and likely most publicized aspect of RI, relates to the potential negative impact that economic liberalization has on employment and on a region's capacity to dampen this impact. Regional agreements invariably include commitments for lowering trade barriers between member states, raising concerns that jobs will be diverted to markets with lower labour costs and that existing labour standards will erode. RI agreements may also include provisions on the free movement of people and labour which may increase competition between neighbouring workers and potentially have important migratory consequences. An analysis of such socio-economic impacts of regional integration will not be the focus of this paper but are, nonetheless, important areas of study for discerning the social impact of RI economic policy on a region's working population. ${ }^{1}$

The second perspective with regard to RI has to do with the institutional character of integration. This is chiefly a governance question about whether regional bodies (where they exist) have the mandate to address social concerns, and if so, how they are in fact addressing them. What role, for example, do regional structures play in regulating labour mobility, overseeing and enforcing labour and employment standards, or in promoting social dialogue and gender equality in the elaboration of regional policies? Additionally, within the African context, what responsibility do these organizations have in regional development and poverty reduction strategies and how, if at all, do these initiatives speak to issues like employment and social security? These inquiries are the main focus of the presentation that follows which, in essence, identifies the present capacity and future potential for RI as a vehicle to promote decent work by drawing on the experiences in West Africa.

Ultimately, separating these two perspectives is artificial since the social policy choices of regional communities cannot be made in a vacuum but must inevitably respond to the real and measured effects that economic integration has on people. This interplay is most

\footnotetext{
${ }^{1}$ There is currently no assessment available on the impact of economic liberalization on workers and the labour market in West Africa, and mostly scattered information on the economic impact of ECOWAS in general. However, a few reports do exist on the impact of the EU-ACP trade initiative in the region, however, their discussion of labour issues is minimal. Consider Sustainability Impact Assessment (SIA) of the EU-ACP Economic Partnership Agreements: Regional SIA: West African ACP Countries, online: <www.sia-acp.org/acp/download/acp_eu_sia_w-africa_2004.pdf> $>$ and Assessing the Impact of ACP/EU Economic Partnership Agreements on West African Countries, online:

$<$ http://fesportal.fes.de/pls/portal30/docs/FOLDER/COTONOU/DOWNLOADS/FESDOWNLOAD S/CONFERENCEPAPERS/HWWA+EPA+STUDY+29.7.04.PDF>.
} 
evident in the strategies adopted by some regions where individuals are compensated through trade adjustment assistance or where certain industries or vulnerable national economies are shielded from foreign competition by adjusted tariff schedules or outright protection. But the point of splitting the analysis in two is to isolate the socio-economic impact of RI trade liberalization from the range of institutional and social policy choices available within an RI grouping. This is all the more relevant considering that over time the initial trade adjustment period will likely pass as economic integration "stabilizes". Yet, the "end" of the adjustment period does not spell an end to the utility of regional institutions which will likely continue to play an active part in the economic and social direction of the community. Not all RI social policies are developed in response to the negative impact of integration. In fact these only represent a negligible part of the social policies typically developed within an RI community (if they even exist at all). Rather, the social dimension of RI is as much about long term governance as it is about countering the immediate social consequences of liberalisation.

This brings us to an important discussion about the nature of regional integration itself in contrast to the narrower phenomenon of regional trade agreements. Trade is an inevitable and often a fundamental part of any regional community and, as in the case of ECOWAS, lowering or eliminating the trade barriers within a region can be one of the first targets of closer economic cooperation. But as developed in greater detail by Daniel Martìnez (2004) there are compelling reasons to treat these two phenomena as distinct one from the other (or at least not to confound them). This is because trade agreements do not typically develop a corresponding social dimension whereas regional integration arrangements do (the EU being the most obvious example). Of course, it is not entirely accurate to suggest that regional integration necessarily includes a social dimension or that trade agreements do not. To take two examples among others, the Association of South East Asian Nations (ASEAN) is a prominent regional community which deals very little with social policy and even less so with the labour dimension of economic integration. On the other hand, the narrowly prescribed US-Cambodia Textile Agreement includes quota incentives that are tied directly to the enforcement and improvement of worker rights in Cambodia's textile and apparel sector (Polaski 2004).

What these brief examples point to, however, is the fact that there are profound differences not only between trade and RI agreements but among them as well. Nonetheless, it is adequate for the purposes of this presentation to mention that when speaking about RI in West Africa, what is being referred to is more than just trade initiatives - especially considering the range of topics covered under the ECOWAS Treaty such as the harmonisation of labour and social security laws, or protocols for the free movement of persons. Whether an isolated trade agreement or a more ambitious regional accord, each integration "instrument" has social and in particular labour consequences (some positive some negative) along with the capacity to address social issues in their own individual way. The essence of the inquiry set out below is: how does West African RI incorporate the social (labour) dimension into its own integration efforts?

Human rights, democratic freedoms and other social welfare concerns need not be alien to the integration process, and for some RI groupings such as MERCOSUR, these principles have always been prominent in regional economic policies. By and large, however, what is typically meant by the word "integration" is the more narrow characteristic of economic harmonisation and free trade. If one looks, for example, at the generally accepted stages of integration $^{2}$, one notices that they are set in almost exclusively economic terms.

2 Deepening regional integration is often described as proceeding along the following path: Preferential Free Trade Area, Free Trade Area, Customs Union, Common Market, Economic Union, Political Union. 
Predictably, preferential free trade is listed at one end of the spectrum and economic union near the other. Political union is then often identified as the apogee of integration, a term which suddenly implies a much larger range of policy options and responsibilities than the stages preceding it. Yet the names used to describe the stages of integration are much less of a problem than what this taxonomy fails to capture - namely, the opportunity for regional communities, at whatever stage of economic integration, to address the social needs of citizens through regional coordination and action.

With this in mind, the International Labour Organization's interest in regional integration comes at a time, particularly since the early 1990s, when globalization has dominated the economic headlines and policy objectives of world leaders. Multilateral negotiations through the World Trade Organization and the plurilateral and bilateral arrangements of smaller country groupings have made enormous progress in reducing tariff and other economic barriers while crafting a vision of economic openness and shared prosperity. Yet over the years, dissenting voices have grown louder in their criticism against the imbalances of this global trend and its failure, up to now, to deliver the promised benefits which so many anticipated.

The report by the World Commission shows the point to which this debate has now reached the mainstream and the urgency needed to rethink existing policies and practices. Among its many recommendations, the report identifies regional integration, not as a liability, but rather as a tool for promoting a more equitable pattern of globalization. This attention given to RI is not entirely novel, however. In fact, the genesis of many of these regional arrangements was grounded in a similar kind of reasoning that advocated combining economic and political resources to lessen a region's vulnerability to external forces, enhancing negotiating power and thereby encouraging growth and higher living standards for their residents. Where the report does make a unique and important contribution, however, is in its proposal that RI must be deepened to embrace social goals and thereby act as a starting point to build these values into the wider global economic system.

Rights at work, employment, social protection and social dialogue - these are the familiar decent work objectives of the ILO which the World Commission identifies as belonging to a broader vision of regional integration. They are also among the priorities for deepening the social dimension of RI and working towards a fairer globalization. Importantly, the social dimension of RI is as much a policy objective as it is a process. One can point to labour standards in trade agreements, the regulation of financial and corporate sectors to ensure respect for fundamental labour rights, efforts to improve social safety nets or the development of human resource policies as social dimension outcomes. ${ }^{3}$ But just as importantly, the social dimension of RI includes democratic participation in an ongoing process of dialogue between public and private actors that serves as a basis for consultation on social and economic concerns. Strong social policies grounded in meaningful dialogue are, therefore, the essence of a social dimension. The extent to which a region incorporates them into its RI scheme is an indication not only of its commitment to these ideals but also of its potential to realize a fairer distribution of integration's benefits to its citizens.

\footnotetext{
3 The concept of the social dimension in this paper focuses primarily on institutions and policies relating to the labour aspects of RI. One must not ignore, however, that the term "social dimension" embraces many other values some of which are included in the ECOWAS Revised Treaty such as the respect for human rights, ecological sustainability and support for cultural industries.
} 


\section{Regional Integration in Africa}

Not unlike other parts of the globe, the African political and economic landscape is moving towards deeper integration. This has led to a patchwork of overlapping Regional Economic Communities (RECs) with a mixed history of success and failure. African RI, however, is not new. Regional integration has been a common feature of the African landscape dating back to the start of the 1960s. ${ }^{4}$ Dealt with only loosely in the Charter of the Organization of African Unity (1963), the role of RI has grown steadily in continent-wide efforts to bring economic development and political stability to Africa. The early proliferation of regional groupings through the 1970s was followed by a commitment in the Lagos Plan of Action (1980) to strengthen existing economic communities and to establish other groupings that would span the entire continent. The OAU's interest in expanding RI was part of a strategy to assemble all the regions together during the initial stages of what would eventually become the African Economic Community (AEC). This push towards African-wide integration, however, is still far from its stated goals with full realization of political, social and cultural integration set for 2028 .

Whatever the permutations of integration in Africa, it is clear that leaders have placed RI high on the political agenda. What is less clear, however, is the commitment to give serious thought to and take appropriate measures on the labour and employment dimensions of regional integration. One of the recurring frustrations for African integration experienced by most communities is the inability to implement the promises of harmonisation on schedule either because of the failure to develop rigorous protocols to put treaty commitments into practice or the failure to meet tariff reduction deadlines. The same pattern is evident, however, in the slow development, if not outright absence, of social considerations in the integration process. In ECOWAS, for instance, it has taken decades for the Community to recognize that it is not enough to promote larger and freer markets without giving due concern to the impacts (both negative and positive) on its citizens and without giving these individuals a voice in the integration process. ${ }^{5}$ That said, even when mechanisms for social policy development and social dialogue are created, these often remain dormant due to insufficient political or financial support. ${ }^{6}$ Consequently, it is not uncommon for written commitments - promising to pay greater attention to the social dimension of integration and to invigorate the social actors - to remain just that.

There is an abiding hope if not expectation that economic unity will promote growth, create jobs and give greater opportunities for Africans to escape poverty. But if regional integration is not buttressed with concerns for the social dynamics of regionalism and does not involve broader social participation in the process, the RECs will not be best equipped to benefit their intended development targets: Africans themselves. The position adopted by the AU’s Abuja Treaty (1991) considers, not surprisingly, that economic cooperation

\footnotetext{
${ }^{4}$ The story of RI in Africa is older still if one considers that the Southern African Customs Union was created in 1910 or the Southern Rhodesia Customs Union in 1949. Yet most of today's RECs came into existence over the past four decades.

5 This is not to mention the role of labour and employment policy in the context of conflict prevention and peace building.

6 Failing to pay Community dues is one symptom of the wider problem of political disengagement from the integration process. This lack of political will may stem from competing domestic interests (for example, where a country's heavy dependence on tariff revenues discourages the prompt removal of tariff barriers), or because of overlapping memberships with other regional economic communities which can have the effect of splitting a country's resources and priorities between coexisting integration groupings.
} 
between neighbouring states can serve as a catalyst for accelerating development. As part of their commitment under this treaty, however, African countries pledged to collaborate in a variety of areas, including human resource development and labour markets, with the main areas of cooperation being education and training, labour mobility, health, employment and labour standards. ${ }^{7}$ Clearly, at the continental level, there is recognition that economic development cannot stand alone without broader social policies supporting it. Whether groups of countries will, together, be successful in fostering these values where individual countries have often failed alone remains an open question.

Most recently, at the AU Heads of State and Government Extraordinary Summit on Employment and Poverty Alleviation ${ }^{8}$, African leaders again acknowledged the role of the RECs in contributing to the socio-economic development of the continent and accordingly gave them shared responsibility, along with Member States, to follow up on the assembly's Plan of Action. ${ }^{9}$ To bring about stronger cooperation between the RECs and to promote economic opportunity, the plan specifically recommends harmonizing community labour legislation as well as establishing mutual recognition of training and skills across borders. Coordinating employment policy is clearly part of the design to introduce a more uniform, or at least compatible, regulatory environment between African countries to encourage investment and cross-border business activity as well as set the stage for broader continental integration. But the Summit's Declaration and Plan of Action go much further in recognizing that regional economic development is contingent on things like greater democratic participation through social dialogue, the empowerment of women and integrating employment issues into regional programmes - all of which confirm that social policies appear to be gaining prominence on the African RI agenda.

\section{Economic Community of West African States (ECOWAS)}

In ECOWAS, more than half of the population (some 115 million people) live on less than one US dollar per day ${ }^{10}$ with 12 of its 15 Member States identified among the world's least developed countries (UNCTAD 2004). Such desperate circumstances inevitably mould and set limits on the RI process. A large uneducated and subsistence-based population is clearly not poised to take advantage of an expanded regional market or the opportunities that might result from a freer flow of goods and capital within the region. But these same difficulties of economic isolation and limited opportunity have driven many countries to adopt regional strategies as a way to overcome domestic weaknesses such as small size, landlocked economies or limited communication and transportation links with the outside world. There is in fact today general acceptance that regional and sub-regional integration efforts offer a promising avenue for addressing the political, economic and social challenges facing African countries in this new age of globalization (ILO 2003c: 8)

In keeping with the character of African RI, ECOWAS is fundamentally a strategy for socio-economic development in West Africa encompassing political coordination and

${ }^{7}$ Treaty Establishing the African Economic Community, 1991, Art. 72.

${ }^{8}$ September 2004, Ouagadougou, Burkina Faso.

${ }^{9}$ In fact, the Follow-Up Mechanism mandates that each REC shall establish a regional follow-up institution within its own structure, suggesting that there is now an obligation on the part of African economic communities to take account of employment issues in their regional policies (AU 2004d: para. 10).

${ }^{10}$ ECOWAS 2002d, p. 8. 
market and regulatory harmonisation. It is also a microcosm of both the struggles and achievements of RI on the African continent. The plans of its founders back in 1975 to unite the original 15 members ${ }^{11}$ towards the goal of creating an economic union are far from being achieved. Yet despite missed deadlines and at times political inertia, the region has pushed for even deeper political and social integration through initiatives such as the Community Court of Justice, the ECOWAS Parliament, and several protocols on the Free Movement of Persons. If the results of integration efforts have not proven as grand as the original ambition, ECOWAS Member States appear committed to keep their integration promises and to expand the role and responsibilities of regional governance beyond matters of trade and macro-economic policy. This expanded role is evident, among other examples, from the intention of West African leaders to use ECOWAS as the coordinating and monitoring agency for the implementation of the NEPAD regional programmes, an approach reflected across the continent in different regional groupings. Perhaps the most dramatic and publicized example of a deepening political cooperation in ECOWAS, however, has involved the activities of the Standing Mediation Committee and the Ceasefire Monitoring Group (ECOMOG), which was set up in 1990 for conflict prevention and management in West Africa.

The existence of ECOMOG offers testimony to how regional policies can and often must adapt to confront the political and social realities of a region. Even when premised on economic integration, RI cannot easily ignore many of the broader and pressing social challenges which have a direct impact on regional economic prosperity. Civil war, drought, famine, graft and corruption are all grave impediments to economic viability and can easily destabilize cooperative efforts between partners unless collective steps are taken to address them. The political and social circumstances of a region are therefore crucial to understanding not just the potential for RI but also its impact on local working populations. The concept of regional integration may be recognizable for many of its standard components, with trade liberalization, macro-economic policy harmonisation and political coordination as some of its most prominent features. Yet the dynamics of integration can vary dramatically between regions particularly where the economic endowments of Member States are at markedly different levels of development, or, as in the case of ECOWAS, there is widespread underdevelopment, poverty and recurring civil unrest.

\subsection{Constraints on West African Integration - WAEMU and Institutional Overlap}

One element among others that is generally seen as an impediment to regional integration in Africa at large (ECOWAS being no exception) is the fact that countries commonly belong to more than one regional arrangement - an overlap that may result in the duplication of responsibilities, potentially conflicting commitments and the waste of already scarce resources. The UN Economic Commission for Africa itself considers the rationalizing of the RECs as a crucial step if these communities are to coalesce into the more ambitious African Economic Community. ${ }^{12}$ This impediment is especially evident in West Africa which is reported to have the largest number of intergovernmental

\footnotetext{
11 The first ECOWAS Treaty was signed at Lagos on 28 May 1975 by 15 original members. Cape Verde joined ECOWAS as the $16^{\text {th }}$ member in 1976. Recently in 2002, Mauritania withdrew from the organization, bringing the total membership back to 15 . The other current members include Benin, Burkina Faso, Côte d’Ivoire, the Gambia, Ghana, Guinea, Guinea Bissau, Liberia, Mali, Niger, Nigeria, Senegal, Sierra Leone and Togo.

12 The ECA's next report, Assessing Regional Integration in Africa (ARIA), will be devoted to studying the rationalization of regional economic communities in Africa.
} 
organizations (IGOs) of any sub-region (Mwamadzingo 2001/2: 7). ${ }^{13}$ Realistically, however, there are only two regional organisations that matter in West Africa (ECOWAS and the West African Economic and Monetary Union (WAEMU $\left.{ }^{14}\right)$ ), particularly with regard to economic integration and the responsibility for developing regional social policies. WAEMU has always been the more economically integrated of the two country groupings, in no small measure due to their shared French colonial history and common currency and to the fact that every member country has been part of this regional group since independence. Given this already natural inclination towards integration, the WAEMU Community has progressed much quicker than ECOWAS on a number of initiatives. In fact, WAEMU already has a monetary and customs union in place whereas ECOWAS has postponed its goal of adopting a common external tariff until 2007 and is still only contemplating strategies for monetary integration.

This unevenness between the progress of WAEMU and ECOWAS economic integration is not necessarily a source of tension or rivalry between the two organizations - even though the Revised Treaty identifies ECOWAS as ultimately the sole economic community in the region. ${ }^{15}$ Many in fact see "multiple-speed" integration as a stimulus rather than as a deterrent of regional integration in West Africa. This same idea appears, for instance, in the context of the African Union where deeper integration of multiple regional economic communities is seen as contributing to and one day fulfilling the objectives of continentwide integration. By the same reasoning, the sub-grouping of WAEMU countries in West Africa is thought of as promoting ECOWAS integration by moving the regional agenda ahead more swiftly, if for the time being unevenly. ${ }^{16}$ Difficulties with this scenario, however, may appear if the trajectories of WAEMU and ECOWAS integration do not line up, not only with regard to the pace of integration but the actual integration policy choices. The ECA reports, however, that most RECs (ECOWAS and WAEMU included) have largely similar economic integration aspirations. But where there is a plurality of initiatives pursuing identical goals within the same region, this will likely result in wasteful duplication, a dissipation of effort, confusion about the goals of integration, and counterproductive competition between countries and institutions (ECA 2004: 41) For its part, the World Bank considers that to achieve deep integration, consolidation of bi-polar institutional structures is essential (World Bank 2001).

\footnotetext{
${ }^{13}$ To bring some semblance of coherence to this multitude of organisations, the ECOWAS Council of Ministers agreed in 1993 to transform all remaining IGOs into specialized agencies by the year 2005.

${ }^{14}$ Also commonly referred to by its French acronym UEMOA (l’Union économique et monétaire ouest-africaine).

${ }^{15}$ Treaty of ECOWAS, 1993, Art. 2(1).

${ }^{16}$ Consider the discussion of variable geometry in African integration in Lyakurwa 1997: 196.
} 
Conscious that a two-track approach to West African integration might be counterproductive and lead to conflicting rules, ECOWAS and WAEMU signed a general cooperation agreement in May of 2004 to "enhance the coordination and harmonisation of their programmes" (ECOWAS 2004e). The two bodies have in fact made similar efforts since 1999 when leaders directed both institutions to rationalize their programmes and avoid duplication. ${ }^{17}$ To synchronize the work of both organizations, this same agreement created a Joint Technical Secretariat to oversee the coordination of integration policies and one can already point to the development of a common regional PRSP as a promising step in this direction. The fusion of the two organizations, however logically appealing, need not be an inevitable step before effective cooperation between ECOWAS and WAEMU can occur, and in fact, leaders appear content with the current "multiple-speed" approach. More important than institutional unity as far as the social dimension of integration is concerned, is being able to recognize when policies are better developed together rather than apart. Migration policy, for instance, is one area where a single coherent West African plan reflects the reality that the movement of migrant workers does not respect regional political boundaries. Setting out uniform rules throughout West Africa benefits workers who cross from one country or region into another, both in terms of facilitating freer movement of the work force by standardizing documentation and immigration regulations, and in terms of ensuring that workers benefit from non-discriminatory employment rules and adequate social protection while away from home. ${ }^{18}$

The overlap of regions is also significant from a strategic point of view for worker and employer organizations. Just as with economic policies, the social policies pursued at the regional level by WAEMU and ECOWAS differ in formulation and are at varying stages of development. That said, what is vital for the elaboration and promotion of regional social policies is the participation of worker groups and employer associations who have a stake in the integration agenda and who represent broad societal interests. However, such groups from countries with commitments to both WAEMU and ECOWAS would have to engage on two separate regional fronts - a situation that poses resource and planning constraints. In making separate efforts to address social concerns inherent in WAEMU and ECOWAS, the social partners risk stretching their energies and thereby dissipating their impact. This reality may also negatively affect the ability of groups across West Africa to coordinate their strategies on regional matters. Despite sharing many issues that are common to regional integration, ECOWAS and WAEMU do not share the same political dynamic or accommodation for social dialogue, preventing the social partners from taking an identical approach to both organizations. For instance, judging from the content of the respective treaties, ECOWAS puts a greater emphasis on the inclusion of social actors

\footnotetext{
${ }^{17}$ The ECA reports that "the growing rapport between ECOWAS and WAEMU has borne fruit in a common programme of action on trade liberalization and macroeconomic policy convergence. ECOWAS and WAEMU have also agreed on common rules of origin to enhance trade, and ECOWAS has agreed to adopt WAEMU's customs declaration forms and compensation mechanisms” (ECA 2004: 42).

${ }^{18}$ See Labour Mobility below. The risk of policy overlap is greater among the WAEMU countries than among the other seven members of ECOWAS. This is because WAEMU States belong to both WAEMU and ECOWAS at the same time and have developed independent policies (on gender for instance) which have equivalents at the ECOWAS level.
} 
(even beyond workers and employers) in the integration process. The modified WAEMU treaty of 2003, on the other hand, makes no reference to the idea of social dialogue and gives only minimal treatment to matters of employment. ${ }^{19}$

The organizational divide is even apparent in the work of the ILO in the sub-region where it has pursued initiatives with WAEMU as part of its technical cooperation project on promoting social dialogue in francophone Africa (PRODIAF). ILO activities on social dialogue with ECOWAS, by contrast, have been minimal. Coincidentally, efforts toward strengthening the capacity of the WAEMU social partners should help them become more familiar with regional issues and strengthen their ability to participate at the ECOWAS level. But focusing on WAEMU is no substitute for more targeted action with the broader regional leadership and institutions of ECOWAS.

\subsection{The Revised ECOWAS Treaty}

The revision of the ECOWAS treaty in 1993 marked an important change both in the structure and the character of West African cooperation. There was a shift to a more "people-centred organization" as opposed to the "overly bureaucratic inter-governmental agency of the past" (Aryeetey 2001: 16), reflecting a new model of integration that was then taking shape in the African political consciousness. In fact, two years earlier in Abuja in the same spirit of regional renewal, African leaders signed into being the African Economic Community, acknowledging that integration on the continent up to that point had been unable to deliver on its economic promises.

It [was] no longer a narrow trade agreement aimed at expanding trade flows within the continent arising from the liberalization of trade and exchange regimes. Fundamentally, it [was] conceived as a long-term development strategy based on a collective self-reliance leading to an autonomous and self-sustained development. The Abuja Concept of integration [was] a holistic approach which [aimed] to integrate economic and non-economic sectors, build new institutions consistent with a self reliant development process, uphold democratic principles and foster new social and cultural values (ADB 2000: 166)

A comparison between the two generations of ECOWAS treaties clearly demonstrates this change of tack. The 1993 version includes many areas of focus never before included in the early aims of the Community. Whereas the founding treaty leaves out issues of employment entirely, the updated instrument is much more attentive to recognizing workers as participants in the integration process and as beneficiaries of economic integration. The aims of ECOWAS laid out at the beginning of both treaties include - in the revised instrument and its predecessor alike - the goal of raising living standards for people in the region. ${ }^{20}$ However, the list of objectives was expanded in the 1993 Treaty to include for the first time a provision for the strengthening of relations and better sharing of

\footnotetext{
${ }^{19}$ Nonetheless, in accordance with its 2003 Annual Report, the WAEMU Commission planned to undertake preparatory activities at the beginning of 2004 leading to an eventual decision by the Union on a framework for tripartite social dialogue. And, despite the limited treatment of social policy matters in the WAEMU Treaty, the Commission includes a Department of Social Development with a mandate embracing higher education, professional training, health, the promotion of the role of women in regional integration, art, culture and new technologies. See also Social Dialogue and Democratic Participation below.
}

${ }^{20}$ Ibid, Art. 3(1). 
information among business men and women, workers and trade unions. ${ }^{21}$ Also, there is a newly added section on the Community's fundamental principles which includes a commitment by Member States to recognize, promote and protect the rights contained in the African Charter on Human and People's Rights (an instrument that includes a number of labour rights ${ }^{22}$ ) as well as a commitment to social justice and popular participation in development. ${ }^{23}$ Beyond these broad principles, however, the Revised Treaty devotes an entirely new chapter to what one might consider as the social dimension of West African integration. ${ }^{24}$ Chapter XI covers a broad spectrum of topics from human resources, to cultural and social affairs, women, population and even the press. But, despite containing some new commitments which were not found in the previous treaty, this chapter is far from an elaborate treatment of regional labour and employment issues.

What provisions actually do exist on employment are clearly not designed to respond to the potential negative impact on jobs and workers resulting from regional economic integration. Rather, like other instances where ECOWAS deals with labour and employment, they are part of a broader development strategy between Member States to enhance the skills and opportunities of local populations to participate in the economic opportunities of the region. There is no enumeration, for instance, of basic labour rights, nor is there provision for trade adjustment assistance - a measure that would understandably be an unlikely response in West Africa given the huge number of people already unemployed in the region and limited government resources. Also, apart from the establishment of a Technical Commission to deal with all matters falling under Chapter $\mathrm{XI},{ }^{25}$ no specific institutional mechanism is created for monitoring the employment effects of regional trade or to adjudicate complaints relating to labour standard enforcement between Member States. Instead, this chapter is primarily a plan to coordinate and harmonize human resource and other social policies. For example, the treaty outlines that Parties should strengthen co-operation in the fields of education, training and employment ${ }^{26}$, encourage the exchange of skilled manpower ${ }^{27}$, undertake to harmonize labour laws and social security legislation ${ }^{28}$ and enhance the economic conditions of women. ${ }^{29}$ These provisions correspond to the deeper integration efforts in West Africa to complement economic with social development following the logic that a better trained regional workforce and better coordinated national employment policies will help release the human potential and thereby enhance the economic promise of ECOWAS.

\footnotetext{
${ }^{21}$ Ibid, Art. 3(2)(l).

${ }^{22}$ Ibid, Art. 4(g). See ECOWAS Community Court of Justice below for further discussion.

${ }^{23}$ Ibid, Art. 4(h).

${ }^{24}$ See Annex 1.

${ }^{25}$ The Human Resources, Information, Social and Cultural Affairs Commission.

${ }^{26}$ Treaty of ECOWAS, 1993, Art. 60(2)(a).

${ }^{27}$ Ibid, Art. 60(2)(c).

${ }^{28}$ Ibid, Art. 61(2)(b). Similar designs to harmonise labour and social security legislation appear at the continental level in the Treaty Establishing the African Economic Community, Art. 72.

${ }^{29}$ Ibid, Art. 63(1).
} 
Ultimately, the Revised Treaty represents an enlarged vision of ECOWAS that goes well beyond economic integration to include social policy integration as well. What remains to be seen is the extent to which these new commitments will be realized. Trade liberalization itself has still not been fully implemented in West Africa and one wonders if similar obstacles will hinder the development of a stronger social dimension. As is discussed in greater detail below, the situation ten years after the coming into force of the Revised Treaty suggests that there is still much work to be done.

\section{Regional Institutions and the Social Dimension of ECOWAS}

\subsection{Council of Ministers}

The second most important political institution in ECOWAS after the Authority of Heads of State and Government is the Council of Ministers. ${ }^{30}$ Despite being a ministerial-level body, the participants are national Ministers of regional integration rather than Foreign Affairs, Trade, Finance or Labour - portfolios that undoubtedly have a profound relevance to West African integration and its social dimension. The Council is charged with making recommendations to the Heads of State on any and all matters relating to the functioning and development of the Community such as its organizational structure, work programmes, or co-ordination and harmonisation of economic integration policies. Although the Revised Treaty permits other Ministers to participate in the Council, to date, national Ministers of Labour have not joined in the deliberations. What is more, the ECOWAS Secretariat reports that no meeting of regional Ministers of Labour has ever taken place. Prior to the Revised Treaty, meetings between Labour Ministers were designed to be held when the need arose to discuss problems affecting workers in the sub-region. ${ }^{31}$ Yet, considering the objectives of ECOWAS to promote an holistic regional development strategy, convening labour meetings on a needs-only basis takes a short-sighted view of labour and employment policy planning. For one, it impedes the continued sharing of experiences between national labour ministries on the problems as well as successes of each country by making such meetings discretionary. Furthermore, it is reduced to a reactive mechanism that discourages governments from taking forward looking and cooperative steps on issues such as migration or common employment and social security policies. But ultimately, a needs-only approach fails to acknowledge labour matters as an important component of integration by relegating it to the fringes of regional governance instead of fully incorporating it into the integration process. To its credit, the ECOWAS leadership has recently decided to institutionalize an annual Labour Ministers' forum to reflect regularly on regional labour and employment matters. ${ }^{32}$

\footnotetext{
${ }^{30}$ Treaty of ECOWAS, 1993, Art. 10.

${ }^{31}$ Decision of the Authority of Heads of State and Government Relating to the Creation of the Organisation of Trade Unions of West Africa, the Adoption of the Check-off System and Meetings of ECOWAS Ministers of Labour (A/DEC.2/7/86), Art. 10.
}

\footnotetext{
32 The first meeting is planned for 2005 and is to be coupled with meetings between technical labour and employment experts from the region.
} 


\subsection{Human Resources, Information, Social and Cultural Affairs Commission}

Among the institutions that exist in ECOWAS ${ }^{33}$, the Revised Treaty establishes eight Technical Commissions to monitor and facilitate the application of the Treaty within specific areas of competence. ${ }^{34}$ One of them, the Human Resources, Information, Social and Cultural Affairs Commission (HR Commission), has only recently become active, holding its first meeting in March 2004. The scope of the HR Commission's work covers a wide range of topics falling under Chapter XI of the Revised Treaty, including those relating to labour and employment. Although counting for only a fraction of its mandate, the Commission is responsible for matters such as collaboration on training and employment, the exchange of skilled manpower between Member States, establishing mechanisms for co-operation between regional institutions (non-governmental included), and the harmonisation of labour laws and social security legislation.

At its inaugural gathering, the HR Commission discussed an array of topics from youth development and the NEPAD Cultural Plan of Action to granting observer status to NGOs within ECOWAS ${ }^{35}$ and the General Convention on Social Security. As expressed by the Deputy Executive Secretary who opened the event, "the meeting was part of the resolve to re-strategise and reposition the Commission to be more proactive and result oriented in its regional programmes" (ECOWAS 2004e: 2). This statement is particularly fitting as concerns the social security convention which had been awaiting final adoption ten years after its preparation. ${ }^{36}$ The Commission's recommendations, including the proposed social security convention, were adopted by the Council of Ministers in July 2004 with implementation scheduled for the following year.

\subsection{ECOWAS Community Court of Justice}

Regional dispute resolution mechanisms may be one entry point for individuals advocating respect for labour rights within regional integration. This approach to advancing the social agenda, however, has elsewhere proven to be of limited success and it is doubtful, given the restrained mandate of the ECOWAS Community Court of Justice (CCJ), that such a venue offers an effective tool to remedy worker injustices in the West African integration process.

Although originally created by the ECOWAS treaty of 1975, the Court - formerly known as the Tribunal of the Community - was rebranded and enshrined in the Revised Treaty. Despite being nearly 30 years old, the Court has seen little activity and was in fact dormant

\footnotetext{
33 The institutions of the Community include: the Authority of Heads of State and Government; the Council of Ministers; the Community Parliament; the Economic and Social Council; the Community Court of Justice; the Executive Secretariat; the Fund for Co-operation, Compensation and Development; Specialized Technical Commissions; and any other institutions that may be established by the Authority. Treaty of ECOWAS, 1993, Art. 6.

${ }^{34}$ Ibid, Art. 22.

35 To date, 13 NGOs have been granted observer status by the ECOWAS Secretariat and following the first meeting of the HR Commission, an additional four NGOs were recommended as potential candidates.

${ }^{36}$ ECOWAS 2004e: 10. See Social Protection below. The original draft of the General Convention was in fact prepared with technical assistance provided by the ILO.
} 
until it recently heard and dismissed its first and only case in April 2004. ${ }^{37}$ The case was brought by a businessman who argued that Nigeria's closure of its border with Benin resulted in lost revenues and was a violation of Nigeria's commitment under the Protocol on the Free Movement of Goods and Persons. The Court's decision to dismiss was not based on the merits of the case, however, but on the restricted access granted to plaintiffs under the Court's protocol. ${ }^{38}$ At present, only Member States can bring actions before the CCJ on behalf of their citizens whereas private individuals and corporations are excluded from launching a suit without their own government's support.

Broadly speaking, the CCJ's mandate is to assist in settling disputes relating to the interpretation or the application of the Revised Treaty's provisions ${ }^{39}$ and, as such, it serves as a potentially crucial forum for resolving disagreements between Member States. Understandably, matters relating to trade, transportation, communication and energy fall within the Court's jurisdiction. However, it is an open question whether or not this mandate extends even further into the realm of human rights (workers' rights among them) since the Revised Treaty arguably incorporates by reference the provisions of the African Charter on Human and Peoples' Rights - a document which covers such topics as freedom of association, working conditions, equal pay and gender equality. ${ }^{40}$

Given the lone judgment of the CCJ, there is no judicial guidance from the Court on whether the drafters of the ECOWAS Treaty intended this enlarged mandate. Nonetheless, there would presently be little value in granting the Court authority to adjudicate in the area of human rights when individuals themselves are prevented from bringing independent claims. This is especially true when one considers that many human and labour rights violations are in fact perpetrated by states against their own citizens. The requirement to bring a human rights suit through one's domestic government would work as an impediment to litigation, since a state could not bring an action against itself and other states might be reticent to meddle in a neighbour's domestic affairs out of political comity.

The potential for a workers' rights dimension in the work of the Court must not, at present, be overestimated since neither the founding treaty nor the CCJ's protocol explicitly grant it the status of a human rights tribunal. The President of the CCJ, Justice Hasine Donli, has herself urged ECOWAS Member States to revisit the question of standing and to give individuals direct access to the Court. In fact, a draft revision to the Court's protocol that contemplates such an amendment has already been prepared for consideration by the Authority of Heads of State and Government. ${ }^{41}$ Justice Donli considers this to be part of an inevitable expansion of the Court's jurisdiction which may one day extend to human rights guaranteed under Community statutes. ${ }^{42}$ But even before achieving this ambitious stage,

\footnotetext{
${ }^{37}$ Olajide Afolabi v. Federal Republic of Nigeria, 2004/ECW/CCJ/04.

${ }^{38}$ Protocol A/P.1/7/91 on the Community Court of Justice, Art. 9(3).

${ }^{39}$ Treaty of ECOWAS, 1993, Art. 76.
}

${ }^{40}$ African (Banjul) Charter on Human and People's Rights, 1981, Art. 2 (gender equality), Art. 10 (freedom of association), Art. 15 (satisfactory conditions, equal pay for equal work).

${ }^{41}$ The draft protocol was scheduled for consideration in November 2004.

${ }^{42}$ Greater attention to the human rights of Community citizens can also be seen in the recent adoption of a bill on human rights and equal opportunity by the ECOWAS Parliament, a measure that first requires the approval of the Authority of Heads of State and Government before coming into force. See online: <http://news.biafranigeriaworld.com/archive/2003/oct/07/0144.html>. 
once individual citizens are given direct access to the Court, they would be able to hold governments accountable to a limited range of rights established under such instruments as the protocols for the free movement of persons, which give the right to seek employment in any Member State, or similarly, under the General Convention on Social Security which guarantees the equal treatment of nationals and non-nationals under domestic law.

The utility of a forum like the CCJ to take up the cause of workers in West Africa is in the end only as strong as the underlying commitment of Member States to the social dimension of integration. As Adelle Blackett insightfully points out, the capacity of RI institutions to address social values amounts to very little when the liberalization process itself is at odds with these deeper concerns (2002: 963). Should access to the court be widened to allow individual applications, the CCJ may yet become a democratic forum for engaging Member States on their social commitments under the ECOWAS Treaty, despite a narrow jurisdiction that presently excludes human rights cases. Nevertheless, one must not lose sight of the fact that the Court was not fundamentally designed for social advocacy but as a mechanism to hold ECOWAS countries to their RI bargain - an underlying purpose that may likely have a greater impact in shaping the role of the Court.

\subsection{ECOWAS Community Parliament}

One of the newest institutions created under the Revised Treaty, the Community Parliament held its inaugural session in January 2001. The powers of this body are much diminished from those commonly held by national parliaments. In fact, the ECOWAS Parliament does not have specific decision-making powers but rather, functions in an advisory capacity, making recommendations to the appropriate community institutions or organs. That is to say, when the Parliament passes a "bill", it is not binding on national governments before it has been adopted by the relevant Community body. Additionally, ECOWAS parliamentarians are not elected, but are selected by member state governments to represent their respective countries. This institutional arrangement makes the Parliament much more of a deliberative body than a legislature and also means that its members are not directly accountable to West Africans. However, its permanence and regional focus make for an institution that is able to bring continuity to the political dialogue and contribute to technical analysis on issues relating to the social dimension of RI. Four out of the thirteen parliamentary standing committees are in fact charged with mandates that would make them appropriate venues for addressing ECOWAS social policy, including human rights and the free movement of persons, social affairs, employment, and women's and children's rights. ${ }^{43}$

Together, the ECOWAS Court of Justice and Parliament are fundamental institutions for regional governance which, over time, and depending on the commitment of leaders to sustain them, may create greater space for democratic participation in the Community and serve as a forum for advancing labour and employment issues within the region and to hold regional leaders accountable for their decisions. However, at present, both the Parliament, just like the Court, are limited in their respective legislative and remedial powers and are at a considerable distance from the centre of influence with respect to the implementation of RI and the development and monitoring of social policies within ECOWAS. Nonetheless, both institutions may very likely become more implicated in the Community's governance and merit close consideration as West Africa progresses towards not only deeper economic integration but social policy coordination as well.

${ }^{43}$ ECOWAS Parliament Rules of Procedure, Rule 38. 


\section{ECOWAS, Employment Law and Workers' Rights}

Although the Revised Treaty displays a greater commitment on the part of ECOWAS Member States to include employment on the integration agenda, the elaboration and enforcement of labour standards remain chiefly matters of national concern. Despite incorporating by reference the African Charter which, as pointed out, includes labour rights among its provisions, there is no insistence that specific labour standards be respected by the Parties in any of the regional instruments, nor is there a social charter. ${ }^{44}$ Yet, the absence of regional standards belies the fact that the vast majority of the 15 ECOWAS countries have ratified most of the fundamental ILO Conventions (see Annex 3). Ten out of the 15 nations have signed all eight instruments, two countries have ratified seven and two more have ratified six. Only one country, Guinea Bissau, has ratified as few as five fundamental Conventions. In addition, it is worth noting that among the nine instances of non-ratification in West Africa, seven of these concern Conventions Nos. 138 and 182 on the abolition of child labour, demonstrating solid and agreement on 6 of the 8 fundamental Conventions. At least formally then, one can say that the governments of the region have shown common support for international standards and, therefore, would be less likely at odds if they were to insist on the incorporation of certain labour rights at the regional level. Yet, regardless of the potential agreement between the Parties on this issue and the possibility for incorporating regional labour standards into the integration framework, the treatment of labour rights has been left largely undeveloped in ECOWAS.

Granted, the focus for adoption and application of labour standards remains at the country level, leaving sovereign nations to regulate employment inside their own borders. This situation confirms at least two things. First, and not surprisingly, the ILO's work in promoting and observing compliance with international labour Conventions is chiefly tied to nation states and not regional organizations. Secondly, although the ILO does not pay great attention by its very constitutional mandate to the elaboration of standards at the regional level, the promotion of regional labour standards nevertheless has a strong connection to national promotion since these countries are the same members who make up regional groupings and who can translate their own domestic commitments into regional practices. Yet, as is clear from other regional approaches (the North American Free Trade Agreement in particular), the incorporation of labour standards alongside a trade or other integration agreement does not invariably lead to the strengthening of labour rights within member countries. They may even undercut the nation-level commitments if expressed as aspirations rather than grounded in the language of rights themselves. Additionally, the universal character of existing international labour standards risks dilution among member countries if they are redefined at the regional level and if, in doing so, they depart from long-standing and universal standards.

Focusing on West African trade agreements and workers' rights for a moment, the ECOWAS Trade Liberalisation Scheme (TLS), which came into force on January 1, 1990, is an instrument for lowering tariff and non-tariff barriers on intra-community trade. Unlike some regional or bi-lateral trade agreements which include labour standards and dispute mechanisms directly in the agreement itself (e.g. Canada-Chile) or in a side agreement (NAALC), the TLS does not create any such commitments between signatory countries. In contrast, the Cotonou Agreement between the European Union and ACP countries (to which ECOWAS is a party), has an explicit provision reaffirming the commitment of each signatory to the ILO's fundamental labour standards. It is not clear,

\footnotetext{
44 The idea of a social charter has, nonetheless, been taken up in the current draft ECOWAS budget and officials suggest that one will be adopted some time in 2005.
} 
however, whether this commits each State to observe all eight fundamental Conventions or only those which they have already ratified. The parties further agree to enhance cooperation on labour standards and not to use such standards for protectionist ends, but beyond this aspirational language, there is no formal mechanism to review country compliance, nor is there mention of how non-compliance would affect trade benefits under the agreement. One final trade initiative applicable in several ECOWAS Member States (the US African Growth and Opportunity Act) goes further than both the TLS and EU/ACP by tying trade benefits directly to the protection of internationally recognized labour standards including

- the right to association;

- the right to organize and bargain collectively;

- a prohibition on the use of any form of forced or compulsory labor;

- a minimum age for the employment of children; and

- acceptable conditions of work with respect to minimum wages, hours of work, and occupational safety and health. ${ }^{45}$

As alluded to in the introduction, trade agreements are often only a small part of a region's broader integration strategy. In an RI grouping such as ECOWAS, social and labour issues are often left to other more targeted instruments (a protocol on the free movement of persons or harmonized employment and social security legislation for example) because the mandate of the Community is not only limited to trade. But one cannot ignore the fact that trade agreements still have the potential to function as tools for promoting labour standards (as attempts in the AGOA and EU/ACP agreements modestly reveal). Nonetheless, among ECOWAS countries, the TLS has not been used to elaborate worker rights, nor do the benefits of trade liberalization within the Community depend on a country's respect for certain labour standards.

One area where there has in fact been some progress in recognizing regional labour standards in ECOWAS is in relation to migrant workers. ${ }^{46}$ This is perhaps not surprising given the necessarily intra-regional nature of migrant labour and the interest of States in protecting their nationals abroad. The free movement of persons has always been a feature of West African integration. Since 1975, the Community has rolled out a three-phase plan to achieve the goal of removing obstacles to the free flow of people between States and to allow Community citizens to take employment or engage in commercial activities in any ECOWAS country. Rather than redefining the rights of migrant workers within the region, the second protocol on the right of residence and establishment refers to rights contained in the ILO Conventions on the protection of the rights of migrant workers. However, under the protocol, these "fundamental rights" only apply to the treatment of migrants upon their expulsion from a Member State's territory. Otherwise, migrant workers are entitled to the same treatment as national workers under a country's domestic laws. This highlights the characteristic approach of ECOWAS which seems to prefer a coordinating legal structure as in the case of migration and social security - and to defer on most other matters to the laws of Member States rather than creating uniform legal standards or codes (see Legal Harmonization below).

${ }^{45}$ African Growth and Opportunity Act, 19 U.S.C. 3701, Sec. 104(a)(1)(F). Burkina Faso and Liberia are not eligible for AGOA preferential trade benefits for a variety of reasons, none of which, however, relate to concerns over worker rights in each country. See online: $<$ http://www.agoa.gov/resources/2004-05-agoa.pdf>.

${ }^{46}$ See Social Protection below for a discussion of the General Convention on Social Security. 
One cannot ignore the fact that efforts at regulatory harmonisation in West Africa, as far as employment is concerned, constitute a predominantly formalistic affair that would not apply to the large number of workers in the region who work in the informal economy. This paper does not, just as ECOWAS largely does not, consider the particular problems of these workers. It is important to mention, however, that any portrait of the labour landscape in ECOWAS is incomplete without considering the character of unregulated work and how the social dimension of regional integration - from its development objectives to employment promoting policies - might address this reality.

\section{Legal Harmonisation}

Legal reform in Africa has itself taken on a regional dimension as can be seen from initiatives in the East African Community (EAC), the Southern African Development Community (SADC) and in Francophone Africa. Shared employment policies and standards are seen as benefiting neighbouring countries by enabling skilled workers, entrepreneurial knowledge and professional services to move more fluidly across borders. In addition, cross-border investment and foreign direct investment are facilitated by harmonizing employment laws between countries since a more coherent regulatory environment offers predictability and cost savings throughout the region. As mentioned earlier, the ECOWAS Revised Treaty contemplates efforts to harmonize labour legislation across all Member States. ${ }^{47}$ Yet there is no mention of the extent or method of such harmonisation (i.e. whether the Parties would draft a common code, agree on a set of principles or standards which then become the responsibility of individual states to incorporate into their domestic legal systems, or simply agree that citizens are entitled to the same treatment as nationals under domestic laws). Presumably, sorting out these considerations will be left to the work of the HR Commission which has competence for labour law harmonisation, but to date no work has been undertaken to consider moving towards regionally compatible employment regulation. Apart from stating legislative harmonisation as an objective, the treaty does not set out guiding principles or common minimum standards for parties to promote in devising an integrated legal regime. Yet this belies the fact, as noted above, that there is a broad consensus on fundamental labour standards across West Africa when one looks at the ratification of ILO Conventions by individual ECOWAS Member States. ${ }^{48}$

The notion of legal harmonisation as a means to deploy a common social policy in ECOWAS puts some of the challenges facing West African integration inter sharper contrast. Apart from the numerous languages spoken in the region, there is also a multiplicity of legal traditions which reflect the colonial and pre-colonial histories of each country. British common law and French civil law dominate the landscape, but one also finds Portuguese civil law and a mingling of customary and traditional legal systems side by side. ${ }^{49}$ The intricacies involved in creating a uniform labour law across these diverse traditions would be a daunting task, suggesting that the strategy of harmonisation identified in the Revised Treaty is likely the more practical and politically feasible approach. But first, it is important to point out some differences between harmonized as compared to

\footnotetext{
47 In traditional common law terms, labour law refers to the rules governing collective bargaining whereas employment law refers to rules governing the relationship between an individual employee and his/her employer. Here, however, I am using the terms generically since ECOWAS itself does not always preserve the distinction in its discussion of legal harmonisation.

48 See Annex 3 below.

49 French civil law (8 countries), English common law (5 countries), Portuguese civil law (2 countries).
} 
uniform legislation. In the context of ECOWAS, harmonisation has involved crafting a regional statute which, though not replacing national legislation, entitles citizens within the Community to equal treatment under the domestic laws of each Member State. This is a particularly important step in a community with policies for the free movement of workers so as to ensure that, legally speaking, foreigner workers are not discriminated against compared to national workers. Uniform laws on the other hand go much further and are designed to replace national statutes with a single shared law or, one might say, a community code. To date, ECOWAS appears only to be contemplating the harmonization of West African labour and social security legislation. ${ }^{50}$ That said, this approach is in contrast to other plans in the sub-region for creating uniform statutes in the area of employment law.

\subsection{Organization for the Harmonisation of Business Law in Africa (OHADA)}

A further example of potential integration “overlap” in West Africa, particularly with respect to legal harmonisation, is seen when one considers the work of the Organization for the Harmonisation of Business Law in Africa (OHADA) ${ }^{51}$ This organization is a regional grouping of 16 predominantly francophone and civil law countries, nine of which are simultaneously members of WAEMU and ECOWAS. ${ }^{52}$ OHADA's stated purpose is to reduce trade barriers and facilitate investments within its Member States through business law harmonisation. But in spite of its name, the organization's mandate extends beyond legal reform and harmonisation of commercial law into the field of employment law - an intention explicitly mentioned in the OHADA treaty as one of its areas of competence. ${ }^{53}$ Following a decision by the OHADA Council, preparatory work has already begun on drafting a labour code drawing on ILO technical assistance and with the participation of labour ministries and national social partners (ILO 2003c: 41). ${ }^{54}$ One important difference between ECOWAS and OHADA, however, is that OHADA, once again in spite of its name, is in actual fact developing uniform laws to supersede the national legislation of Member States.

One must then ask how ECOWAS' efforts at legal harmonisation, particularly in the field of employment law, will proceed given the similar objectives and overlapping membership between OHADA and ECOWAS countries and the progress OHADA has already made on labour law and other legal reforms. The potential for contrasting policy points of view and even legal dissonance within ECOWAS is a real possibility as long as there are different and uncoordinated "harmonisation" projects at work. To avoid the risk of duplicated efforts and potentially incoherent results, the ECOWAS Secretariat is now considering how the OHADA framework might be adapted to synchronize business law in the remaining ECOWAS countries. This same framework may be similarly applied to other legal efforts in West Africa in the area of labour and employment law, providing once

50 In addition to labour law and social security law, however, ECOWAS also intends to harmonise national investment legislation ultimately leading to the adoption of a single Community investment code (Treaty of ECOWAS, 1993, Art. 3(2)(i)).

${ }^{51}$ L'Organisation pour l'Harmonisation en Afrique du Droit des Affaires, online: $<\underline{\text { http://ns1.cm.refer.org/ohada_cm/> }}$.

\footnotetext{
52 See Annex 4.

53 Treaty on the Harmonisation of Business Law in Africa (1993), Title I, Art. 2.

${ }^{54}$ Completion of the uniform labour code is expected for January 2006.
} 
again an example of how, despite the overlapping initiatives, the "multiple-speed" integration approach may serve to encourage and hasten deeper integration in ECOWAS as a whole.

\subsection{Labour Mobility and Workers' Rights}

In addition to harmonizing employment legislation in ECOWAS, the free movement of persons is considered to be a key component towards the economic growth of the Community that will enhance the flexibility and availability of labour in the sub-region while enlarging opportunities for workers. In their first protocol from 1979, ECOWAS Member States called upon one another to allow fellow citizens to work freely anywhere within the region. As a result, citizens of the Community no longer require entry visas to travel into the territory of other member States. ${ }^{55}$ And in 2000, the ECOWAS passport was introduced, which is ultimately designed to replace national passports to further facilitate the mobility of people throughout West Africa. In addition, under the Community's Revised Treaty, citizens are guaranteed the right of residence and establishment throughout the sub-region, ${ }^{56}$ which includes the right to apply for and take up employment in the territory of any Member State.

Such "human" integration and labour mobility encourage a range of different cross-border work scenarios characterized by differing degrees of physical permanence or transience in another state. At one end of the spectrum are workers who cross over international boundaries but only temporarily (as is often the case in the transportation sector). At the other end, some workers move permanently into a foreign country in search of work while still remaining nationals of their home State. But, although the ECOWAS policy is ostensibly designed to bring about such free flows of labour across borders, national leaders are often cautious about the effect that such a policy might have on their domestic labour markets. One fear is that by opening up a country's borders to the influx of foreign labour, the already limited job opportunities available to local residents will be put under greater pressure from outside labour competition - a fear particularly evident in countries that perceive themselves to be at a disadvantage in terms of skilled labour compared to their neighbouring countries. ${ }^{57}$

The road to full mobility in ECOWAS was supposed to follow three successive phases of deeper transition over a period of 15 years. Yet, despite the ambitions of the initial Free Movement of Persons Protocol, the ECOWAS Secretariat reports that there are still many lingering challenges to the policy's full implementation. Getting rid of visa requirements, for instance, "has not spared citizens of the Community administrative harassment and

\footnotetext{
55 The ECA reports that visa exemptions are not unlimited since citizens of ECOWAS Member States may enter and reside in any other Member State for up to 90 days, but must obtain an official permit to stay beyond that period. Nevertheless, the ECA also reports that the provisions of the Free Movement of Persons Protocol are generally respected throughout the Community (ECA 2004: 199).

${ }^{56}$ Treaty of ECOWAS, 1993, Art. 59(1).

${ }^{57}$ For instance, the labour and finance ministries of Côte d'Ivoire decided jointly on 19 February 2004 to adopt a decision giving Ivorians priority over non-Ivorians in all types of jobs from "qualified labour to manual labour" - a decision that triggered sharp criticism within ECOWAS. Online:

http://www.irinnews.org/report.asp?ReportID=40009\&SelectRegion=West_Africa\&SelectCountry= COTE_D_IVOIRE.
} 
extortion at border posts ${ }^{\text {} 58}$ and there are still many security check points set up along international roads. Ultimately, difficulties facing cross-border and immigrant workers are greater than those experienced by nationals. Such hindrances are among several reasons why cooperation and integration in labour mobility has not been fully achieved in West Africa. The ARIA report adds that insufficient political commitment and resources, linguistic barriers, lack of expertise, uneven compliance with Community obligations and persistent economic crises along with high unemployment in many of the countries are further obstacles to the free movement of labour, exacerbated by high population growth which strains resources for educational development and social assistance (ECA 2004: 200).

For its part, the ILO recently completed a technical cooperation project on labour migration in West Africa which was launched to investigate migration as a key to promoting economic development within the context of regional integration. ${ }^{59}$ As recognized by the ECOWAS Secretariat itself, the project addressed the fact that barriers continue to exist to the free movement of labour in the region despite joint regulatory efforts to the contrary. The study further considered a host of persistent migration challenges such as: the poor linkage between migration and development processes; inadequate administrative and institutional capacity for effective migration policies and management; the lack of protection for migrant workers; the poor quality of migration statistics; as well as the loss of human capital through the emigration of highly skilled workers.

While all of the foregoing obstacles need to be addressed in their own way, developing common labour standards as well as complimentary and universal social security rules at the Community level remains an important underlying strategy to protect workers who move between Member States. ${ }^{60}$ It similarly provides consistent ground rules for a common labour market which ensure greater opportunities for skills, entrepreneurial knowhow, technology and professional services to be exchanged between countries. However, action on shared employment policies and social protection schemes has been slow to develop in ECOWAS in spite of the commitment of the Revised Treaty to harmonize these fields of law across the sub-region.

\subsection{Social Protection}

The range of different cross-border working scenarios within an integrated labour market raises a number of issues. Among them is the concern that, since social security is a matter of national competence, migrant workers risk being excluded from work-related benefits unless appropriate legal guarantees are in place between regional partners. Mindful of this risk to the security of migrant workers in West Africa and hoping to facilitate the flow of

\footnotetext{
${ }^{58}$ ECOWAS Secretariat, online: <http://www.sec.ecowas.int/sitecedeao/english/regional-2.htm\#>.

59 The project took into account initiatives of both sub-regional bodies (ECOWAS and WAEMU) although it primarily undertook a review of migration law and practice in WAEMU countries (a region which has its own policy on the free movement of persons and the right of establishment). For details of this ILO project and its documented findings see online: <http://mirror/public/english/protection/migrant/projects/africa04.htm>.

60 The Protocols also guarantee the protection of workers who are expelled from a given country by, among other things, stating that no expulsion may take place without ensuring that the migrant worker's fundamental rights have been respected (rights which incorporate by reference the ILO Conventions on the protection of migrant worker). See ECOWAS Supplementary Protocol A/SP/.1/7/86, Arts. 1 and 16.
} 
persons and labour across the sub-region, the Social and Cultural Affairs Commission for ECOWAS adopted the General Convention on Social Security in 1993 to ensure the equality of treatment for cross-border workers and the preservation of their rights when living abroad. ${ }^{61}$ Drafted in consultation with the ILO, this multilateral treaty represents a synthesis of Member States' social security systems and replaces all social security agreements previously concluded between ECOWAS Member States. In its particulars, the instrument reflects the substance of two specific ILO Conventions: the Equality of Treatment (Social Security) Convention, 1962 (No. 118) and the Maintenance of Social Security Rights Convention, 1982 (No. 157). The agreement ensures that individuals residing in a given ECOWAS country have the same rights and obligations under the social security laws as do nationals of that same country. The General Convention further sets out provisions for determining the applicable legislation depending on the employee's working circumstances.

The scope of the General Convention extends to every worker who qualifies for social security benefits including his or her family members and survivors, and is applicable to all national legislation covering the following branches of social security:

- invalidity, old-age and survivors' benefits;

- benefits in respect of occupational injuries and diseases;

- family and maternity benefits; and

- sickness benefits.

Because each Member State has its own social security regime, the Convention also provides that the competent authorities share information on their domestic systems and assist one another in the application of the Convention. Coordination between the States is necessary for ensuring accountability and the even application of the Convention, This coordination is strengthened by the existence of a Committee of Experts ${ }^{62}$ capable of centralizing and disseminating such information. The Committee is designed not only to foster cooperation between countries in the field of social security but is also authorized to give more direct assistance to migrants themselves. This is an important practical dimension to the Committee's work since migrant workers are often poorly informed about the legal protections available in a host country. Among the tools at its disposal to help overcome this ignorance, the Committee is authorized to prepare informational materials to educate migrant workers on their rights and how to enforce them.

\footnotetext{
${ }^{61}$ See Treaty of ECOWAS, 1993, Art. 61(2)(b). The General Convention was only recently adopted by the Council of Ministers.

${ }^{62}$ The Treaty of ECOWAS, 1993, Art. 40(3) states that "the Committee shall receive technical assistance from the International Labour Office”.
} 


\section{ECOWAS and Development Frameworks}

\subsection{Towards a Regional Poverty Reduction Strategy Paper (PRSP)}

The ILO has been involved to different degrees in supporting poverty reduction strategies in five ECOWAS countries, ${ }^{63}$ many of which are at various stages of PRSP development. The ILO's involvement has been primarily to empower the social partners to influence the drafting of PRSPs in order to incorporate aspects of decent work while at the same time influencing organizations and governments involved in this process to embrace these same priorities. Primarily a tool for developing plans on a country by country basis, PRS initiatives have no equivalent at the regional level. Nonetheless, in line with NEPAD's objectives and following a decision by the Council of Ministers in 2001, ECOWAS decided to pursue the development of a regional poverty reduction programme. This programme is not intended to replace the national plans but rather as a means to complement the country PRSPs, enabling Member States to insert a regional dimension into their poverty reduction strategies. It acknowledges that, as a tool for economic management, a common approach to PRSPs between West African neighbours will be an effective way to bolster country development and donor support in line with the ECOWAS goal of reducing poverty among its Member States along the path towards a common market. The regional approach would encourage the sharing of experiences and best practices and ensure that the regional dimensions of poverty reduction are incorporated into the national PRSPs and that the regional integration programmes contribute as much as possible to poverty reduction.

The World Bank has not traditionally endorsed regional PRSPs and in its Regional Integration Assistance Strategy (RIAS) for West Africa formulated in 2001, the Bank explains that matters such as human resource development and poverty reduction should be the domain of national governments. But following consultations, it was agreed that a tentative proposal be made towards the preparation of a West African PRSP. This decision responds in large measure to the absence of a regional component within national PRSPs combined with the belief that many regional issues, such as labour migration and crossborder social security are integral to a comprehensive poverty reduction strategy particularly within the context of regional economic integration. Conceptually, the Bank considers that a single PRSP that addresses regional strategies might focus on how RI can increase economic growth, increase opportunities for the poor to be gainfully employed and earn higher incomes, and how RI can enhance national programs to deliver essential public services to the poor, both to improve their skills and to assure that minimum needs are met (World Bank 2001).

ECOWAS is not alone in taking an interest in regional PRSPs. Its neighbour organization, WAEMU, has similarly made progress in the drafting of its own poverty reduction strategy. The World Bank has been actively encouraging West African nations to fulfill their poverty reduction mandate and is collaborating with both ECOWAS and WAEMU to help develop and implement a regional plan. This collaboration has led to the creation of technical units on poverty reduction in each of the three organizations and a joint technical team has been set up by ECOWAS and WAEMU to coordinate the drafting of a single PRSP for West Africa.

\footnotetext{
${ }^{63}$ Benin, Burkina Faso, Mali, Niger and Senegal. See Johansen and Buckley (2004).
} 
During discussions between the Bank and ECOWAS officials, however, a "cautionary note was voiced" about the potential complexity and cost of developing a regional poverty reduction strategy. This reservation related in part to the desire to include civil society groups in regional PRSP deliberations - a feature now considered essential in the creation of national strategies. Obviously, drafting a regional PRSP involving 15 Member States in consultation with workers, employers and civil society groups from across the region would pose logistical challenges and likely result in more intricate and protracted negotiations. But, to its credit, the Bank noted that broad social dialogue was a highly desirable feature that should be reproduced at the regional level.

\subsection{The New Partnership for Africa's Development (NEPAD)}

One of the most prominent examples of ECOWAS's role in West African socio-economic development is seen in its participation in the African Union's NEPAD initiative. This African-led development plan considers partnerships as an integral component to the development strategy, which is why NEPAD advocates a hastening of regional and continental integration. However, deeper and more lasting economic integration is not only one of its ambitious policy objectives, but in fact serves as a key for delivering many of the development projects throughout Africa. Although individual countries are considered as the drivers and owners of NEPAD, regional economic communities have a prominent place in the programme's execution, making ECOWAS the natural focal point in West Africa for implementing the plan.

But beyond this emphasis on regionalism, ECOWAS leaders also realize that they share many of the same NEPAD policy and programme priorities that were adopted by the AU Assembly in 2002. Although setting out a number of objectives and broad implementation guidelines, NEPAD does not specifically address what plans of action or institutional mechanisms are necessary to move this development initiative forward. It was logical, therefore, that West African Heads of State adopt a regional approach towards the implementation of NEPAD and designate ECOWAS as its regional focal point. The coincidence of these strategies is seen not only as facilitating the implementation of NEPAD by incorporating it into an operational institutional framework but also as shoring up support, both inside and outside of Africa, for ongoing ECOWAS integration.

NEPAD has nonetheless been criticized for being formulated without broad-based consultation and for not including an effective social dimension in its development mandate ${ }^{64}$ Another criticism leveled against NEPAD is its failure to develop a strategy to deal with unemployment and underemployment even though these are among the primary reasons for poverty. ${ }^{65}$ In its founding document, NEPAD deals briefly with human resource development initiatives that touch on the empowerment of women and the poor, expanding educational opportunities and implementing policies to reverse the "brain drain". Conspicuously, there is no mention of labour issues. The lack of attention paid to employment in NEPAD, however, might be seen to have been remedied in part by the work of the recent AU Extraordinary Session on Employment and Poverty Alleviation. There, the AU Members identified with much greater clarity the significance of

\footnotetext{
${ }^{64}$ ICFTU-AFRO, Regional Conference on the Challenge of Globalization in Africa: The Role of Trade Unions in Promoting Balanced Development, online: < http://www.transafricaforum.org/newsletter/news_june\%2011_02_icftuafro.html>.

${ }^{65}$ Godfrey Kanyenze offers a critique of the New Partnership for Africa's Development (NEPAD) for the Zimbabwe Congress of Trade Unions (ZCTU). Online:

$<$ http://www.africaonline.co.zw/theworker/Archive/Aug/augcasep.html>.
} 
employment and the decent work development agenda, and the crucial role of the RECs in implementing these policies. Although properly not a part of NEPAD, the recent AU commitments fill a gap in the social dimension of African development that was otherwise glaring.

\section{Social Dialogue and Democratic Participation}

Social dialogue is the most fundamental component towards building an integrated social dimension into regional integration. An open and participatory process that includes governments, workers' and employers' organizations and even other interested social actors has the potential to address a diversity of interests and to achieve legitimacy in the eyes of the stakeholders. Furthermore, as part of a development strategy, strengthening the capacity of social actors and encouraging them to contribute to the integration process has benefits beyond cultivating the social dimension. It also has the effect of encouraging greater democratic participation and strengthening of local governance. As was pointed out by ECOWAS itself, Community decisions sometimes rely on the direct or indirect implementation by non-governmental actors, making the social partners important conduits for regional action.

Yet the ability of social partners to engage with the regional leadership depends first on the willingness of the Community to listen to these other points of view and, secondly, on the capacity of the social actors to coordinate and effectively deliver their message. This second aspect is of particular importance in the context of regional integration where institutions for national social dialogue do not have a connection to the regional decision making process, requiring new links and partnerships between regional social partners to forge a coordinated response to RI. But the responsibility for addressing social issues should not be left to the social partners alone. Member States have the means to give a regional platform to social dialogue by incorporating not only the values of democratic participation into regional decision-making but, more concretely, by setting up and supporting mechanisms that create space for this dialogue to take place.

\subsection{The Legal Framework}

Reflecting the change in focus to more "people-centred" policies, the 1993 ECOWAS Treaty has scattered references and commitments to the idea of social participation and dialogue. The original ECOWAS Treaty included, as it does today, a Social and Cultural Affairs Commission designed to "provide a forum for consultation generally on social and cultural matters affecting the Member States" ${ }^{66}$ Yet there was no indication that such consultations were open to non-governmental actors, and in actual fact, the participation of worker and employer groups in the early development of the Community was negligible. It was not until the Revised Treaty that ECOWAS began crafting mechanisms to create space for broader social participation in the integration process.

The centrepiece of the Revised Treaty, as far as social dialogue is concerned, is found in Articles 81 and 82, whereby the Community not only commits to cooperating with nongovernmental and socio-economic organizations, but in both instances, also commits to setting up mechanisms for consultation with these organizations. Article 82 in particular makes explicit reference to workers and employers among those whose involvement in the integration process should be encouraged. Yet beyond these commitments, the Revised

\footnotetext{
${ }^{66}$ Treaty of the Economic Community of West African States, 1975, Art. 49.
} 
Treaty does not specify how, for example, the social partners would be formally consulted. Details about consultation are fleshed out in a separate ECOWAS decision ${ }^{67}$ which introduces regulations for granting observer status to non-governmental organizations to participate in the Community's institutions. Under this statute, organizations are divided into two categories (A or B) depending on their level of interest in ECOWAS activities. An organization qualifies for an "A" designation if it (1) has a basic interest in the activities of the Community; (2) is closely linked with the social and economic life of the area which it represents; and (3) has made sustained contributions towards the attainment of Community aims and objectives. In comparison, "B" certifications are given to organizations which only have a general interest in the activities of the Community. The difference between the two designations is essentially that " $\mathrm{A}$ " observers have privileged access to the ECOWAS Council of Ministers whereas " $B$ " observers are only accredited for Institutions other than the Authority and the Council. Having the privileged " $A$ " observer status entitles an organization to:

(a) send observers to all public meetings of Council;

(b) be invited by Council to make oral presentations;

(c) circulate documents to Members of Council;

(d) be invited to collaborate with any Committee as may be established by Council;

(e) submit questions or views for insertion in provisional Council agendas for all meetings except those of the Authority; and

(f) consult with the Executive Secretariat on matters of mutual concern.

Presumably, an organization of workers or employers would qualify under these rules and benefit from "A"-level access to the ECOWAS organs, whether or not they are of a local or regional character. Regional-level organizations would certainly be well-suited as observers, but the question is not whether an organization has cross-country membership or activities but simply whether it has an interest in the Community's activities as a whole - a more inclusive standard that shouldn't impose an unwarranted barrier to the participation of small, nationally based groups in Community deliberations. Still, both the resurrected Organization of Trade Unions in West Africa and the embryonic West African Employers' Organization (see below) have not as yet taken advantage of the ECOWAS observer status. The reasons for this do not appear to be the result of Community resistance to the contributions of workers and employers in the RI process. Clearly, the Community's legal framework and ECOWAS officials are receptive. Nonetheless, these two constituents have yet to capitalize on the dialogue opportunities available to them.

The Protocol on Democracy and Good Governance is yet another Community instrument showing the commitment of Member States to develop broader social participation in the region. ${ }^{68}$ Its provisions reveal some interesting characteristics about social dialogue in

67 ECOWAS Decision A/DEC.9/8/94 Establishing Regulations for the Granting to NonGovernmental Organisations (NGO's) the Status of Observer Within the Institutions of the Economic Community of West African States.

${ }^{68}$ ECOWAS Protocol A/SP1/12/01 on Democracy and Good Governance:

Article 28(1): "Employers and trade unions shall be organized an/or strengthened in each Member State and at the regional level of ECOWAS."

Article 28(2): "Member States shall promote social dialogue. In this regard, employers associations and workers unions shall meet regularly among themselves and with political and administrative authorities with a view to preventing social conflict.” 
West Africa. For one, in recognizing that dialogue is an integral feature for managing the social concerns within ECOWAS, regional leaders acknowledge that it is not simply enough to welcome a wider range of voices into the discussion, especially when these voices often do not exist, or are too weak to be effective. The weakness of the social partners in many of the ECOWAS countries is, on its own, an obstacle to the inclusion of worker and employer interests in the pursuit of deeper integration, and more fundamentally to the democratic processes and accountability of Member States. Furthermore, the encouragement of social dialogue in West Africa has perhaps as much to do, if not more, with fostering a climate of peace and stability in the region as it does with inviting other actors to sit around the ECOWAS table. Social dialogue in ECOWAS is therefore both part of a political strategy and a development policy - an approach reaching well beyond efforts to merely consult workers and employers on RI initiatives.

Formally, ECOWAS encourages participation of the traditional ILO social partners and civil society in the work of the Community. In practice, however, this participation is imperfect despite practical efforts by ECOWAS to create space for participatory dialogue within the regional institutions. Part of the explanation may very well lie in the lack of political will to follow through and make truly effective the commitment to bring the social partners into the inner decision-making circle. Yet, one cannot ignore the fact that in a region of such under-development, unemployment and poverty, employer and worker groups themselves (where they exist) face significant organizational and resource obstacles that hinder their capacity to engage at the regional level, even when the mechanisms are in place to do so. ${ }^{69}$

In response to this reality, Community Members have urged one another to take a more active role in creating national and regional employer organizations and trade unions - an initiative that invites cautious optimism given the concerns that naturally arise when a government takes an active hand in creating supposedly independent bodies.

\subsection{Organization of Trade Unions in West Africa (OTUWA)}

The importance of union participation in the West African integration process extends well beyond matters of regional economic integration alone. As discussed, regional communities across Africa are the focal point for a number of trade and development projects from NEPAD and the negotiation of Economic Partnership Agreements with the European Union, to PRSPs and the future creation of a continent-wide African Economic Community based on linking the existing RECs. Each of these initiatives (ECOWAS integration included) formally recognize the importance of seeking the participation of all interested stakeholders, which at least nominally creates space for worker organizations to give substantive input. Still, despite all of these projects and their undeniable relevance to labour and employment in West Africa, regional coordination between unions has been weak and the resulting influence on regional initiatives inconsequential. That said, one cannot ignore that union advocacy can be an effective tool at the national level, even with regard to sub-regional issues. This is understandable when one considers that ultimately,

\footnotetext{
${ }^{69}$ David Dorkenoo, head of the International Department of the Trade Union Congress (Ghana), confirmed that the difficulty in finding resources to organise regional trade union meetings is an acute problem and an obstruction to dynamic regional union advocacy.
} 
ECOWAS is a collection of nations rather than a sovereign regional authority responsible for RI. Local unions and national labour congresses may therefore effectively lobby domestic leaders to adopt policies that address the labour and employment concerns relating to economic integration. Still, there remains an undeniable role for regional collaboration between local unions which together can combine their financial and technical resources to participate more consistently and meaningfully, not just as individual national units but within the ECOWAS framework itself.

OTUWA was founded in the mid-1980s in response to a need for a permanent regional organization to coordinate the action of ECOWAS workers. Created by the Authority of Heads of State and Government as an official Community organization, OTUWA was designed with its financial sustainability in mind through provision of a national check-off system which would allow it to collect dues from members through payroll deductions. ${ }^{70}$ As contained in its statutes, OTUWA's aims and objectives are:

- to give strong support to the economic integration process and to work towards the attainment of its economic, social and cultural objectives;

- to draw up a programme for the control of unemployment and the integration of youth into the labour force; and

- to protect the rights of migrant workers through policies of free movement, rights of establishment and the harmonisation of Member States' labour and social security legislation.

The organization was only recently revived after a long period of inactivity when new officers were elected in August of 2003.

Despite its scheme for direct membership support, OTUWA nonetheless suffers from financial constraints which, among other things, make it difficult for its executive members to meet. ${ }^{71}$ Not surprisingly then, OTUWA has been unable to make much progress on its original goals. Through its recent revival, however, members have taken tentative steps to reposition the organization as a participant in regional dialogue. Following a recent strategic executive meeting in April 2004, members agreed among other things to hold seminars/workshops on trade and regional integration, as well as launch a Technical Group dedicated to trade issues that would link its work to the activities of the ECOWAS Secretariat. ${ }^{72}$ Additionally, members agreed on the need to increase research on migrant labour and to take steps to re-establish political contact with the ECOWAS Secretariat. Not unlike the ECOWAS Secretariat, the OTUWA executive has made peace and security in West Africa one of its top priorities, which involves plans to help renew the trade unions of Sierra Leone and Liberia following years of social unrest and armed conflict. Such work will undoubtedly help strengthen union activism across the region and OTUWA's role as a representative association.

Although OTUWA is the most representative union association in ECOWAS, it is not the only regional workers' organization in West Africa. Not surprisingly, unions from

\footnotetext{
${ }^{70}$ Supra note 31.

${ }^{71}$ To correct its underfunding problem, OTUWA members recently agreed that they should each pay annual dues and that Governments in the sub-region should lend their financial support.

${ }^{72}$ A policy workshop was held during the same month where the effects of international trade and trade agreements on workers in the sub-region figured prominently on the agenda. OTUWA examined trade rules under the WTO, the United States African Growth and Opportunity Act (AGOA), the EU Economic Partnership Agreements and how workers and trade unions in West Africa can develop their capacity to make enduring contributions to these processes.
} 
WAEMU Member States have formed their own alliance based in Ouagadougou called $L a$ Coordination Syndicale, which is devoted to promoting decent work, social and economic rights, union rights and social dialogue within the sub-region. Although focussed largely on the concerns of workers falling within the WAEMU integration zone, La Coordination Syndicale nonetheless recognizes its role in promoting an expanded RI under the ECOWAS banner and has recommended that its membership consider ways in which it can contribute to broader union activism across West Africa. ${ }^{73}$ The activities of OTUWA and La Coordination Syndicale offer yet another example of the overlap between the two regional organizations but, not unlike the idea of "multiple-speed" integration, the parallel activities of these two regional unions need not work at cross purposes where they can instead build upon one another's relationships with local workers and unions and benefit from shared resources.

A discussion of regional unions is incomplete however without once again pointing out that the representation of these organizations does not reach a substantial number of informal economy workers - a number that has been growing exponentially in sub-Saharan Africa and which clearly faces a representational problem within the context of regional integration (Delvaux 2001/2).

\subsection{Employers' Organizations}

In February 2003, West African employers, with support from the ILO's Bureau for Employers' activities (ACT/EMP), convened a sub-regional workshop in Burkina Faso to discuss the role of employers' organizations in regional integration. ${ }^{74}$ The gathering focused on the contribution of the private sector towards the economic development of West Africa, as well as on building stronger ties between employers across the region to coordinate and promote their particular interests. One thing the participants agreed upon was the need to concentrate their efforts on assisting small and medium enterprise (SME) development. In order to "allow the West African SME to fulfill its role as the motor for regional integration", the employers suggested that certain underlying elements were indispensable if ever the region hoped to enjoy sustainable socio-economic development. These included the promotion of social dialogue at local, national and regional levels, the improvement of human production factors, the creation of an optimal business climate to foster decent work and thereby combat poverty, and the setting up of human resource strategies based on competences and employability.

To pursue these regional objectives, the participants agreed to an engagement strategy focusing on the activities of employer representatives at three different levels: governmental, regional and local. Regionally, employers called for the creation of a "federative structure" uniting employers' organizations from ECOWAS member countries as a means to create a forum of exchange and dialogue and to better combine the activities of the West African private sector - which, to that point, had been largely uncoordinated. That said, there do exist other regional linkages in the private sector through organizations such as the West African Enterprise Network (WAEN) or the Federation of West African Chambers of Commerce. WAEN, for instance, was founded in 1993 with the purpose of

\footnotetext{
73 Statuts de la coordination syndicale des centrales syndicales des pays membres de l'union économique et monétaire ouest africaine (WAEMU), Arts. 3 and 26; Recommendation from the Conférence sous-régionale des centrales syndicales des Etats membres de l'WAEMU, 14-18 October 2002, Bamako.

${ }^{74}$ See Conclusions, Regional Integration and International Cooperation in the ECOWAS: The role of Employers' Organizations, 25-26 February 2003, online at: http://www.ilo.org/public/english/dialogue/actemp/conf/2003/ouagadougoue.pdf.
} 
examining policy reform issues, advocating change to the business environment within individual countries, and promoting cross-border trade and investment in the sub-region. Counting a membership of some 300 business men and women from 12 countries, WAEN nevertheless does not appear to have had much involvement in, let alone impact on, the regional social policy debate since it is more a consortium of business and investor interests than a forum for employers with a particular stake in regional labour and employment matters. The participation of the private sector in the ECOWAS integration process has been limited. This situation is not lost on the ECOWAS leadership which considers economic prosperity to depend in large measure on the efforts of the business community and, in matters of human resource development and employment, on the participation of employers in RI dialogue.

\subsection{Civil Society}

Only recently, civil society groups in West Africa have become formally engaged in the process of regional integration despite the fact that even back in 1993, the Revised Treaty called upon the Community to co-operate with regional NGOs to encourage the broad participation of citizens in the integration process. ${ }^{75}$ In December 2003, the first ever West African Civil Society Forum ${ }^{76}$ (WACSOF) brought together some 100 representatives from across the region in an initial effort to institutionalize their relationship with ECOWAS. ${ }^{77}$ Funded and endorsed by ECOWAS itself, the Forum was prompted by the prior lack of inclusion of civil society organizations (CSOs) in the work of regional institutions and also by the lack of coordination between civil society groups themselves in bringing a critical and coherent perspective to the many policy implications of West African integration. In a statement, the ECOWAS Executive Secretary, Dr. Mohamed Ibn Chambas, spoke of his personal commitment to strengthening the institutional ties with civil society and to building their capacity to intervene more fully in the sub-region's activities. As a measure of this commitment, Dr. Chambas announced that a Civil Society unit would be created in the ECOWAS Secretariat with the goal of harmonizing the disjointed and divergent civil society initiatives. In fact, this focal point now exists but has not undertaken any work in relation to labour or employment matters. It appears that the priority of the focal point is to strengthen the capacity of CSOs to support policy development and implement ECOWAS programmes in relation to regional peace and security concerns.

The draft WACSOF Charter describes itself as a partner and advisor of ECOWAS with the objective of promoting "permanent dialogue between West African civil society and the ECOWAS Secretariat on vital issues concerning West Africa and its future". The Forum is designed to enhance the capacity of civil society to contribute to regional policy formulation by, among other things, undertaking studies independently or at the request of ECOWAS, and by working with all the organs of ECOWAS and participating in their activities where necessary. With regard to the institutional structure of the forum, ten

\footnotetext{
75 Treaty of ECOWAS, 1993, Art. 81.

76 Report on the West African Civil Society Forum, Accra, December 2003. Online at: http://www.wildaf-ao.org/docs/word/press/WACSOF_final_report_Dec03.doc.

${ }^{77}$ In another measure to build ties between ECOWAS and regional non-governmental organisations, the Council of Ministers established a Forum of Associations Recognized by ECOWAS (FARE) in 1996. The stated purpose of FARE is to coordinate all NGO activities as well as provide a liaison between the Associations and the Executive Secretariat. The forum is open to those who have been granted observer status - including worker and employer groups. See Regulation C/REG.5/11/96 Establishing a Forum of Associations Recognized by ECOWAS (FARE).
} 
working committees are envisioned with mandates over such things as gender, regional integration, economic development and trade, yet there is no committee responsible for labour and employment matters.

The absence of a committee dedicated to labour and employment issues is not reflective, however, of the Forum membership which includes worker and employer organizations, market women, retail traders, artisans and farmers among the ranks of non-governmental social groups. ${ }^{78}$ Greater institutional attention given to the concerns of these groups must be considered as a positive development. However, the goodwill shown on the part of regional officials represents only a modest and late beginning to including broader social dialogue in the integration process. Significant progress and hardening of regional policies has already occurred since 1975 without the benefit of a more democratic debate. It will be interesting to see how, at this stage, the nascent advocacy of West African civil society and workers and employers will contribute to the RI discussion in the region and, more importantly, how seriously their contributions will be taken by political leaders. Coordination between such groups and the Secretariat must therefore move beyond the administrative level to include meaningful participation in Council of Ministers deliberations. The Secretariat's initiative is an important step towards that end, but as a framework for real social dialogue on labour and employment matters, the civil society focal point shows only limited promise. ${ }^{79}$ As emphasized by Minister Apraku of Ghana,

the framework must provide the inputs and modalities for effective engagement of West Africa Civil Society within the ECOWAS process. The framework must create an opportunity for West Africa Civil Society to fully partner the ECOWAS in undertaking major initiatives that will contribute significantly to the development of the sub-region. ${ }^{80}$

Regardless of the work remaining to be done, in the author's opinion it is encouraging that the relationship between civil society and government in the region is turning towards constructive efforts to involve broader social voices in the RI process and to recognize that such groups have an important role in promoting democratic governance, security and social development in West Africa.

\section{Gender and ECOWAS}

This paper has touched frequently upon the idea that regional integration in Africa is predominantly a development agenda which strives not to exploit existing dynamic economic forces between countries (which are by and large weak) but, in a cooperative way, to prepare the soil in which dynamic economies can grow. One of the principle concerns of many social actors in Africa is that RI agreements have concentrated heavily on capital and natural resource mobilization without adequate consideration for the role of

\footnotetext{
${ }^{78}$ Draft Charter of the West African Civil Society Forum (WACSOF). Online:

$<$ http://www.google.ca/search?q=cache:RwNyXBEJ4UsJ:www.wildafao.org/docs/pdf/press/WACSOF_charter_ENG.pdf+draft+charter+wacsof\&hl=fr\&lr=lang_en|lang fr>.

79 This is particularly true when one considers the wide range of possible topics covered by civil society groups in West Africa and that the Secretariat focal point, as a mechanism for collaborating with all of these groups, would necessarily have a diffuse mandate.

${ }^{80}$ From the keynote address by the Honourable Dr. K. K. Apraku, Ghanaian Minister of Regional Cooperation and NEPAD, at the opening ceremony of the first ECOWAS civil society forum. Accra, 11 December 2003.
} 
human resources - a priority which, at least rhetorically, has shifted in West Africa with ECOWAS' new commitment to people-centred policies. But beyond poverty eradication, the creation of decent jobs or the respect for international labour standards, integrating gender-sensitive regional policies and removing barriers that prevent women from becoming active participants in the economic life of a community are equally important pieces of the development puzzle and the future economic success of the region.

The Revised ECOWAS Treaty recognizes this much by addressing the need to create and harmonize coherent gender policies within Member States, to identify and remove constraints inhibiting the involvement of women in RI efforts and to promote dialogue to deal with these concerns. ${ }^{81}$ This shared purpose at the Community level for the welfare of women is partly reflected in the commitments of individual ECOWAS States to international conventions on women and discrimination. For instance, each of the 15 members is a party to the UN Convention on the Elimination of All Forms of Discrimination Against Women ${ }^{82}$ along with the ILO's Discrimination (Employment and Occupation) Convention, 1958 (No. 111). Within ECOWAS, only Liberia has yet to ratify the ILO's Equal Remuneration Convention, 1951 (No. 100). ${ }^{83}$ Given the prominence of these legal instruments as a basis for pursuing gender equality, the technical committee on gender policy in ECOWAS requested that the prohibition of gender discrimination be incorporated into all ECOWAS statutes relating to women (no such provision appears in the Revised Treaty). This commitment to include a gender dimension in the instruments and activities of the Community is an important policy focus considering the already mentioned development and trade initiatives in ECOWAS such as the proposed regional PRSP, the NEPAD plan of action ${ }^{84}$ and the negotiations towards an EU Economic Partnership Agreement.

The World Commission on the Social Dimension of Globalization reports that the effects of trade liberalization have historically posed a threat to the livelihood of women producers and that women are often economically marginalized in terms of ownership and access to credit because of bias in the policy and regulatory environment. Yet regional integration can present many opportunities for women to find better paid and more secure work, thereby offering the hope of economic independence (ILO 2004a: paras. 215-217). The challenge then, for a region such as ECOWAS, is to capitalize on the potential of women as contributors to the broader development goals in West Africa increasing the representation of women in regional policy decision-making bodies, being attentive to the impact of economic and social policies on women in the region and, promoting initiatives to mobilize women in the Community building process. Yet, the disadvantages that women face in West Africa go well beyond the potential negative effects of regional trade and economic integration. In an assessment of the current social landscape for women in the sub-region, it was observed that there are gender disparities in virtually every sector:

In general, women are at a disadvantage in terms of access to education, legal rights, health status, political and other forms of representation, in access to economic resources and in participation in, and benefit from, economic programmes (ECOWAS 2004b).

\footnotetext{
${ }^{81}$ See the Treaty of ECOWAS, 1993, Art. 63 (Women and Development).

${ }^{82}$ United Nations Division for the Advancement of Women, Department of Economic and Social Affairs. Online: < www.un.org/womenwatch/daw/cedaw/states.htm>.

${ }^{83}$ See Annex 1.

${ }^{84}$ Apart from poverty reduction, development, and ending the marginalization of Africa in the world economy, one of the primary objectives of NEPAD is to accelerate the empowerment of women.
} 
Faced with such grave and fundamental problems, the potential ill-effects of economic liberalization in West Africa are just some of the systemic challenges confronting women. Yet, as mentioned, instead of making things worse, RI, and Community strategies that take into account the circumstances and perspectives of women, hold some promise for overcoming these disadvantages.

One attempt to include a gender perspective into the integration process came about through the creation of the West African Women's Association (WAWA) in 1987 - a specialized technical institution of ECOWAS designed to oversee and develop genderrelated matters. Disappointingly, WAWA never became much of a going concern. Ultimately, the organization was abandoned and replaced by the Gender Development Centre in $2003 .^{85}$ This transformation followed a recommitment to mainstream gender issues within the Community and the drafting of an ECOWAS Gender Policy, which benefited in part from ILO technical assistance. The new policy direction seeks to address the strategic interests of men and women in promoting the social, economic and cultural development of West Africa, by capitalizing on the cooperative energies of regional integration and on the various development strategies and commitments, such as NEPAD and the Millennium Development Goals, which both put gender high on the development priority list. Unlike previous efforts, the ECOWAS Gender Policy sets out a more ambitious operational structure for gender mainstreaming within the Community through what it calls the Gender Management System. ${ }^{86}$ This is in response to the fact that prior institutional and staffing arrangements did not sufficiently allow for the incorporation of gender issues into the ECOWAS plans and programmes. It remains now to be seen if the newest reincarnation of the Community's gender policy will surmount the management and political problems that prevented WAWA from fulfilling its original purpose.

\section{Conclusion}

One objective of this paper (apart from setting out a taxonomy of processes and policies for socially responsive integration in ECOWAS) has been to highlight the strategies available to African RECs in their efforts to include a broad social mandate within economic integration. It also points out some of the nagging obstacles to crafting and implementing regional social policies. As is clear from the ECOWAS example - and what can be gathered from the general trend across the continent - is that regional economic communities are largely viewed as engines for socio-economic development. As such, the ambitions of African integration often surpass mere trade liberalization or shared economic policies to touch on fields of education, health, job creation, peace and security, cultural affairs, the press and the free movement of people.

However, the scale of ambition is often times rivaled by numerous limitations. One common limitation concerns the lack of resources for supporting regional projects. The reasons for inadequate resources can be found, on the one hand, at the domestic level where individual countries face budgetary constraints that make it difficult to follow

\footnotetext{
${ }^{85}$ Decision A/DEC.16/01.03 Relating to the Transformation of the West African Women Association (WAWA) into the ECOWAS Gender Development Centre, 31 January 2003, Dakar.
}

${ }^{86}$ The Gender Management System structure consists of the Gender Commission, the ECOWAS Secretariat's Gender Management Team, Gender Division and Gender Focal Points, the ECOWAS Gender Development Centre and the National Bodies Responsible for the Advancement of Women. 
through on the many regional commitments requiring local level implementation. On the other hand, an equally stubborn institutional problem that is symptomatic of political disengagement is the failure of some States to keep up with regional membership dues, thereby endangering the ability of secretariats and other community organs to function properly.

These same constraints hamper not only the move towards more integrated regional markets but also the successful implementation of regional social policies. The harmonisation of labour standards within ECOWAS for instance - an important objective where a Community envisages a common labour market - requires both political and financial support. Yet despite having plans on paper to develop such legislation, there has been no real progress to date, and one cannot be overly optimistic considering that regional labour ministers have still not formally met to discuss labour concerns within ECOWAS. Greater progress has been made, however, as seen in the recent adoption of the General Convention on Social Security, another key component for protecting worker rights as the region heads towards a more integrated labour market. Nonetheless, simply identifying the legal measures adopted by a region is an insufficient indication of the success of regional social processes and policies. More targeted and empirical follow-up research is needed to assess the effectiveness of these measures and their impact on the working population of West Africa.

The social partners in ECOWAS have had limited success in participating in the process of integration despite the formal mechanisms set up for this very purpose. And, as briefly mentioned, organized workers in the formal sector represent only a small proportion of the West African workforce which is predominantly in the informal economy. The weak coordination between worker and employer groups at the regional level, the limited resources of these constituents to devote their energies to regional issues, the linguistic and political divides resulting from the two regional structures in West Africa and, importantly, the inability thus far of member governments to foster broad democratic participation in the integration process all contribute to the current absence of vibrant social dialogue within ECOWAS.

Promoting and incorporating the social dimension of RI within a given region needs strong social partners. The social dimension cannot truly be representative or legitimate without wider and real democratic participation in the organs of the community. Furthermore, such participation is only sustainable through a continued political commitment on behalf of regional member States to cultivate a practice of effective social dialogue. But even where the political will and institutional mechanisms for social dialogue exist (as appears to be the case in ECOWAS), the participation of workers and employers in the integration process may nonetheless be weak or entirely absent either because they lack the resources, regional coordination, political mandate or simply the awareness of the relevant issues. The current situation of regional workers' (OTUWA) and employers' organizations in ECOWAS epitomizes the challenges in creating intra-regional links between social partners and expose the possibility of an uncoordinated and therefore less forceful critique of regional economic and social policies.

As has been amply discussed, the overlap of RI communities and initiatives poses an obstacle to effective and coherent social policy in West Africa. Considering the rate of integration in the WAEMU Community and the accomplishments to date of OHADA on legal harmonization, the centre of regional social policy development in West Africa is not confined to ECOWAS alone. Whether these disparate projects will help or hinder ECOWAS' stated intention of becoming the dominant West African Community is not yet clear. The forthcoming work by the Economic Commission for Africa on rationalizing the RECs will present an opportunity for greater reflection on the effects of overlapping communities on regional labour and employment policy, particularly in the domains of labour migration and labour standards. 
The ILO's increased interest in the process of regional integration and its impact on working people can serve as a basis for greater involvement on a variety of fronts. In his report to the International Labour Conference in 2004 on the World Commission's findings, the Director-General noted that the ILO is called upon "to offer advice on ways in which institutions and policies for decent work could provide a foundation for regional integration processes" (ILO 2004b: 14). Among other things, this requires closer collaboration between the regional structures of the ILO and communities such as ECOWAS, the promotion of mechanisms for social dialogue within these same communities and a commitment to knowledge-sharing and regional capacity building on the social dimensions of globalization. The ILO can work at encouraging regional institutions and governments to pay closer attention to the social impact of RI, not simply in pursuit of the ILO's principles and legal instruments but as a policy which compliments economic integration and development.

To be successful in this respect, the ILO must engage community leaders both at the national and regional levels and must strengthen, or as is often the case, create new ties with regional institutions as a means of knowledge-sharing and dialogue. ${ }^{87}$ To date, only SADC and the EAC out of all the African RECs have signed formal arrangements (memoranda of understanding) with the ILO covering consultation, exchange of information, joint activities, attendance of meetings and the provision of expertise. Notably, the EAC agreement goes beyond simply structuring a relationship between the two organizations and mentions specific areas of policy consultation (employment creation, vocational training, labour law harmonisation, social dialogue and social security). Memoranda of understanding represent only a limited, though practical, first step in creating stronger links between the ILO and regional communities. Undoubtedly a myriad of other measures would promote organizational cooperation, particularly on specific technical projects with more identifiable outcomes. But whatever mechanisms are used, there is an opportunity, and one can even say a willingness, on the part of some African RECs ${ }^{88}$ to concretize efforts on the social dimension of RI.

${ }^{87}$ In March 2003, the Declaration Expert-Advisers expressed their hope that the ILO would pursue closer ties with regional institutions and they specifically identified ECOWAS as a possible candidate (ILO, Governing Body doc. GB286/4, 286 ${ }^{\text {th }}$ Session, Geneva, March 2003, para. 23).

${ }^{88}$ The recent ECOWAS mission to the ILO (November 2004) and the resulting Memorandum of Understanding currently under negotiation were in fact both initiated by ECOWAS itself. 


\section{Annex 1 - Chapter XI of the Revised Treaty of ECOWAS \\ CHAPTER XI CO-OPERATION IN HUMAN RESOURCES, INFORMATION, SOCIAL AND CULTURAL AFFAIRS}

\section{ARTICLE 60 HUMAN RESOURCES}

1. Member States undertake to co-operate in the full development and utilisation of their human right resources.

2. To this end, they shall take measures to:

(a) strengthen co-operation among themselves in the fields of education, training and employment; and to harmonise and co-ordinate their policies and programmes in these areas;

(b) consolidate their existing, training institutions, improve the efficacy of their educational systems, encourage exchanges between schools and universities, establish equivalences of academic, professional and technical qualifications, encourage literacy, promote the teaching and practice of the official languages of the Community, and establish regional centres of excellence in various disciplines;

(c) encourage the exchange of skilled manpower between Member States.

\section{ARTICLE 61 SOCIAL AFFAIRS}

1. Member States undertake to cooperate with a view to mobilise, the various sections of the population and ensuring their effective integration and involvement in the social development of the region.

2. For the purposes of paragraph 1 of this Article, Member States undertake to:

(a) encourage the exchange of experiences and information on literacy, professional training and employment;

(b) harmonise their labour laws and social security legislations;

(c) promote women's and youth organizations and professional associations as a means of ensuring mass involvement in the activities of the Community;

(d) encourage and strengthen co-operation amongst themselves in health matters; and

(e) promote and enhance the practice of sports with a view to bringing together the youth of the region and ensuring their balanced development.

\section{ARTICLE 62 CULTURAL AFFAIRS}

1. Member States undertake to pursue the objectives of the Community Cultural Framework Agreement.

2. To this end, Member States undertake to: 
(a) encourage the promotion, by every means possible, of all forms of cultural exchange;

(b) Promote, develop and, where necessary, improve structures and mechanisms for the production, propagation and utilisation of cultural industries; and

(c) promote the learning and dissemination of a West African language as a factor in Community integration.

\section{ARTICLE 63 WOMEN AND DEVELOPMENT}

1. Member States undertake to formulate, harmonise, co-ordinate and establish appropriate policies and mechanisms, for enhancement of the economic, social and cultural conditions of women.

2. To this end, Member States shall take all measures necessary to:

(a) Identify and assess all constraints that inhibit women from maximising their contribution to regional development efforts; and

(b) provide a framework within which the constraints will be addressed and for the incorporate of women's concerns and needs into the normal operations of the society;

3. At the Community level, Member States shall:

(a) stimulate dialogue among themselves on the kinds of projects and programmes aimed at integrating women into the development process;

(b) establish a mechanism for co-operation with bilateral, multilateral and nongovernmental organizations; and

(c) promote and development mechanisms to encourage the exchange of experiences and information between Member States.

\section{ARTICLE 64 POPULATION AND DEVELOPMENT}

1. Member States undertake to adopt, individually and collectively, national population policies and mechanisms and take all necessary measures in order to ensure a balance between demographic factors and socio-economic development.

2. To this end, Member States agree to:

(a) include population issues as central components in formulating and implementing national policies and programmes for accelerated and balanced socioeconomic development;

(b) formulate national population policies and establish national population institutions;

(c) undertake public sensitisation on population matters, particularly among the target groups; and

(d) collect, analyse and exchange information and data on population issues.

\section{ARTICLE 65 INFORMATION RADIO AND TELEVISION}

1. Member States undertake to:

(a) co-ordinate their efforts and pool their resources in order to promote the exchange of radio and television programmes at bilateral and regional levels;

(b) encourage the establishment of programme exchange centres at regional level and strengthen existing programme exchange centres;

(c) use their broadcasting and television systems to promote the attainment of the objectives of the Community. 


\section{ARTICLE 66 THE PRESS}

1. In order to involve more closely the citizens of the Community in the regional integration process, Member States agree to co-operate in the area of information.

2. To this end they undertake as follows:

(a) to maintain within their borders, and between one another, freedom of access for professionals of the communication industry and for information sources;

(b) to facilitate exchange of information between their press organs; to promote and foster effective dissemination of information within the Community;

(c) to ensure respect for the rights of journalists;

(d) to take measures to encourage investment capital, both public and private, in the communication industries in Member States;

(e) to modernise the media by introducing training facilities for new information techniques; and

(f) to promote and encourage dissemination of information in indigenous languages, strengthening co-operation between national press agencies and developing linkages between them. 


\section{Annex 2 - Regional Economic Communities in Africa}

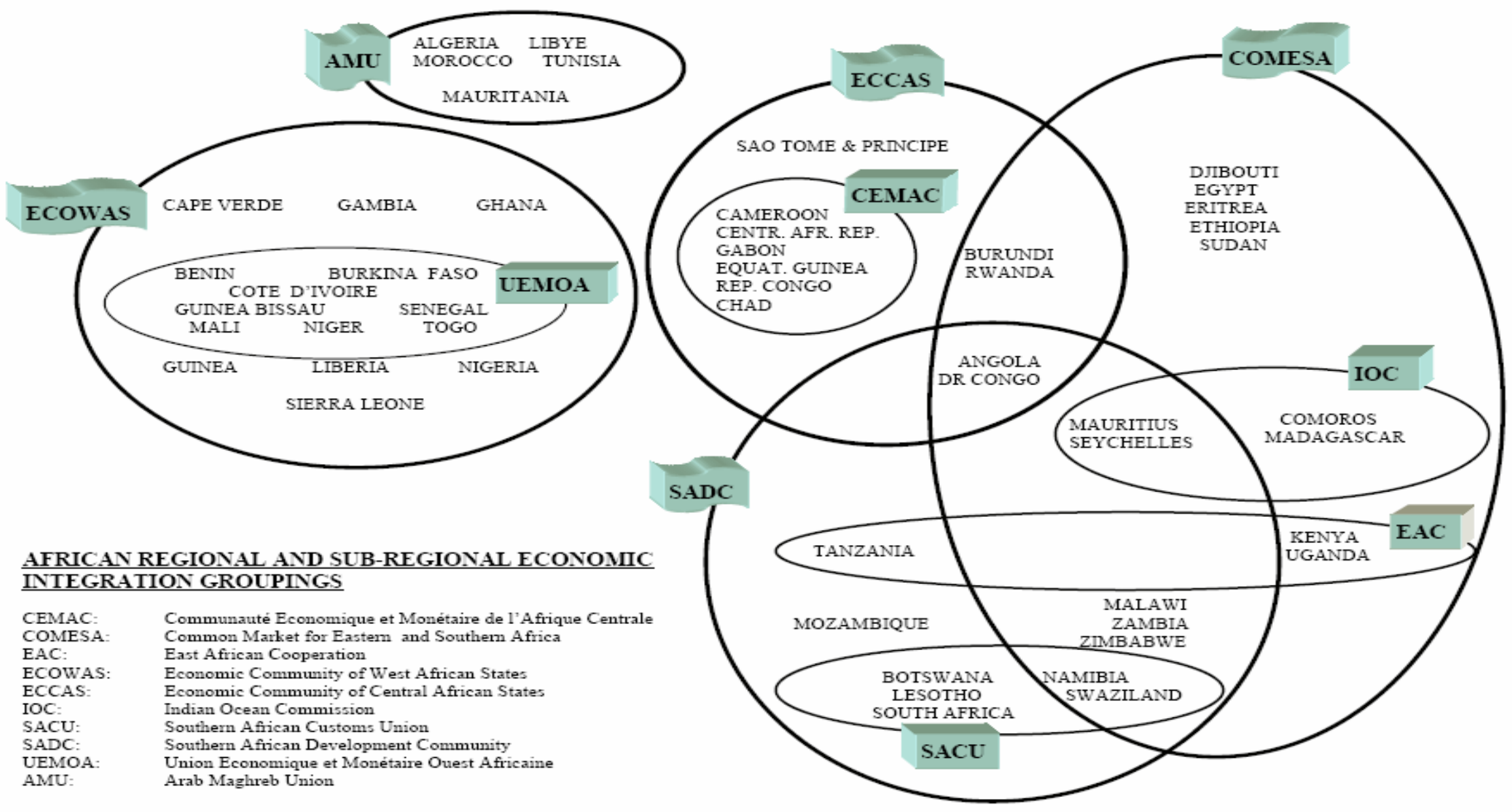




\section{Annex 3 - ECOWAS Member States and the ILO Fundamental Conventions}

\begin{tabular}{|c|c|c|c|c|c|c|c|c|}
\hline \multirow[b]{3}{*}{ Benin } & \multicolumn{2}{|c|}{$\begin{array}{c}\text { Freedom of } \\
\text { association and } \\
\text { collective bargaining }\end{array}$} & \multicolumn{2}{|c|}{$\begin{array}{l}\text { Elimination of forced } \\
\text { and compulsory } \\
\text { labour }\end{array}$} & \multicolumn{2}{|c|}{\begin{tabular}{|c|} 
Elimination of \\
discrimination in \\
respect of employment \\
and occupation
\end{tabular}} & \multicolumn{2}{|c|}{$\begin{array}{l}\text { Abolition of child } \\
\text { labour }\end{array}$} \\
\hline & C. 87 & C. 98 & C. 29 & C. 105 & C. 100 & C. 111 & C. 138 & C. 182 \\
\hline & 12:12:1960 & 16:05:1968 & 12:12:1960 & 22:05:1961 & $\mid 16: 05: 1968$ & 22:05:1961 & 11:06:2001 & 06:11:2001 \\
\hline $\begin{array}{l}\text { Burkina } \\
\text { Faso }\end{array}$ & $21: 11: 1960$ & |16:04:1962 & $21: 11: 1960$ & 25:08:1997 & 30:06:1969 & 16:04:1962 & 11:02:1999 & 25:07:2001 \\
\hline $\begin{array}{l}\text { Cape } \\
\text { Verde }\end{array}$ & 01:02:1999 & 03:04:1979| & 03:04:1979 & 03:04:1979 & 16:10:1979 & 03:04:1979 & & 23:10:2001 \\
\hline $\begin{array}{l}\text { Côte } \\
\text { d'Ivoire }\end{array}$ & 21:11:1960 & 05:05:1961 & 21:11:1960 & 05:05:1961 & 05:05:1961 & 05:05:1961 & 07:02:2003 & 07:02:2003 \\
\hline $\begin{array}{l}\text { The } \\
\text { Gambia }\end{array}$ & 04:09:2000 & 04:09:2000 & 04:09:2000 & 04:09:2000 & 04:09:2000 & 04:09:2000 & 04:09:2000 & 03:07:2001 \\
\hline Ghana & 02:06:1965 & 02:07:1959 & 20:05:1957 & $15: 12: 1958$ & 14:03:1968 & 04:04:1961 & & 13:06:2000 \\
\hline $\begin{array}{l}\text { Guinea- } \\
\text { Bissau }\end{array}$ & & 21:02:1977 & 21:02:1977 & 21:02:1977 & 21:02:1977 & 21:02:1977 & & \\
\hline Guinea & 21:01:1959| & 26:03:1959 & 21:01:1959 & 11:07:1961 & |11:08:1967 & 01:09:1960 & 06:06:2003 & 06:06:2003 \\
\hline Liberia & 25:05:1962| & 25:05:1962 & 01:05:1931 & 25:05:1962 & & 22:07:1959 & & 02:06:2003 \\
\hline Mali & 22:09:1960| & 02:03:1964 & 22:09:1960 & 28:05:1962 & $\mid 12: 07: 1968$ & 02:03:1964 & 11:03:2002 & 14:07:2000 \\
\hline Niger & 27:02:1961| & 23:03:1962 & 27:02:1961 & 23:03:1962 & 09:08:1966 & 23:03:1962 & 04:12:1978 & $23: 10: 2000$ \\
\hline Nigeria & 17:10:1960| & 17:10:1960 & 17:10:1960 & 17:10:1960 & 08:05:1974 & 02:10:2002 & 02:10:2002 & 02:10:2002 \\
\hline Senegal & 04:11:1960 & 28:07:1961 & 04:11:1960 & 28:07:1961 & 22:10:1962 & 13:11:1967 & 15:12:1999 & 01:06:2000 \\
\hline $\begin{array}{l}\text { Sierra } \\
\text { Leone }\end{array}$ & 15:06:1961| & 13:06:1961 & 13:06:1961 & 13:06:1961 & 15:11:1968 & 14:10:1966 & & \\
\hline Togo & 07:06:1960| & 08:11:1983 & 07:06:1960 & 10:07:1999 & $08: 11: 1983$ & 08:11:1983 & 16:03:1984 & 19:09:2000 \\
\hline
\end{tabular}

As of 18 October 2004 
Annex 4 - ECOWAS Member State Profiles

\begin{tabular}{|c|c|c|c|c|c|}
\hline & $\begin{array}{l}\text { WAEMU } \\
\text { Member }\end{array}$ & $\begin{array}{c}\text { PRSP } \\
\text { Development }\end{array}$ & $\begin{array}{c}\text { OHADA } \\
\text { Member* }\end{array}$ & $\begin{array}{c}\text { WTO } \\
\text { Member }\end{array}$ & AGOA Eligible \\
\hline Benin & $\mathrm{X}$ & $\mathrm{X}$ & $\mathrm{X}$ & $\mathrm{X}$ & $\mathrm{X}$ \\
\hline Burkina Faso & $\mathrm{X}$ & $\mathrm{X}$ & $\mathrm{X}$ & $\mathrm{X}$ & \\
\hline Cape Verde & & $\mathrm{X}$ & & Observer & $\mathrm{X}$ \\
\hline Côte d'Ivoire & $\mathrm{X}$ & $\mathrm{X}$ & $\mathrm{X}$ & $\mathrm{X}$ & $\mathrm{X}$ \\
\hline The Gambia & & $\mathrm{X}$ & & $\mathrm{X}$ & $\mathrm{X}$ \\
\hline Ghana & & $\mathrm{X}$ & & $\mathrm{X}$ & $\mathrm{X}$ \\
\hline Guinea & & $\mathrm{X}$ & $\mathrm{X}$ & $\mathrm{X}$ & $\mathrm{X}$ \\
\hline Guinea-Bissau & $\mathrm{X}$ & $\mathrm{X}$ & $\mathrm{X}$ & $\mathrm{X}$ & $\mathrm{X}$ \\
\hline \multicolumn{6}{|l|}{ Liberia } \\
\hline Mali & $\mathrm{X}$ & $\mathrm{X}$ & $\mathrm{X}$ & $\mathrm{X}$ & $\mathrm{X}$ \\
\hline Niger & $\mathrm{X}$ & $\mathrm{X}$ & $\mathrm{X}$ & $\mathrm{X}$ & $\mathrm{X}$ \\
\hline Nigeria & & & & $\mathrm{X}$ & $x$ \\
\hline Senegal & $\bar{X}$ & $\mathrm{X}$ & $\mathrm{X}$ & $\mathrm{X}$ & $\mathrm{X}$ \\
\hline Sierra Leone & & $\mathrm{X}$ & & $\mathrm{X}$ & $\mathrm{X}$ \\
\hline Togo & $\mathrm{X}$ & & $\mathrm{X}$ & $\mathrm{X}$ & \\
\hline Total out of 15 & 8 & 12 & 9 & 13 & 12 \\
\hline
\end{tabular}

* The non-ECOWAS members of OHADA (7) include:

Cameroon, Central African Republic, Comoros, Congo,

Gabon, Equatorial Guinea and Chad. 


\section{Bibliography}

ADB, 2000. African Development Report 2000: Regional integration in Africa. African Development Bank, Oxford University Press, Oxford.

Adegbite, L., 1983. “The need for integration of legal systems among ECOWAS states”, in Readings and Documents on ECOWAS, A.B. Akinyemi et al. (eds.), 479-481.

Adepoju, A., 2002. "Fostering Free Movement of Persons in West Africa: Achievements, Constraints, and Prospects for Intraregional Migration”, International Migration, vol. 40(2), p. 3.

Angula, C.; Jauch, H., 2000. "Regional Economic Integration: A Challenge for the Labour Movement in Southern Africa", paper presented at a panel discussion of the Namibia Economic Society (NES), Labour Resource and Research Institute, September.

Aryeetey, E., 2001. “Regional Integration in West Africa,” OECD Technical Paper No. 170, March.

Association of Ghana Industries; DI International Consultancy, 2000. "ECOWAS is Dead - Long Live ECOWAS: A study of Ghana and regional integration”, September.

AU, 2001. The New Partnership for African Development. African Union, Abuja.

2003. "Building an African Union for the $21^{\text {st }}$ Century”, Issue paper following brainstorming by the AU Commission, Regional Economic Communities and African Financial Institutions, Addis Ababa, November.

2004a. "Coordination Meeting Between the Commission of the African Union and the Regional Economic Communities”, African Union Press Release No. 069/2004, 29 June.

2004b. "Declaration on Employment and Poverty Alleviation in Africa", Assembly of the African Union Third Extraordinary Session on Employment and Poverty Alleviation, EXT/ASSEMBLY/AU/3 (III), Ouagadougou.

2004c. "Draft Plan of Action”, Assembly of the African Union Third Extraordinary Session on Employment and Poverty Alleviation, EXT/ASSEMBLY/AU/4 (III) Rev. 3, Ouagadougou.

, 2004d. "Follow-Up Mechanism for Implementation, Monitoring and Evaluation”, Assembly of the African Union Third Extraordinary Session on Employment and Poverty Alleviation, EXT/ASSEMBLY/AU/5 (III), Ouagadougou.

2004e. "Draft Report", Assembly of the African Union Third Extraordinary Session on Employment and Poverty Alleviation, PRC/EXP/DRAFT/RPT, Ouagadougou.

Babalola Ajulo, S., 2001. "Sources of law of the Economic Community of West African States (ECOWAS)”, Journal of African Law, 45, vol. 1, 73-96.

Blackett, A., 2002. "Toward Social Regionalism in the Americas”, 23 Comparative Labor Law \& Policy Journal 901.

Busse, M.; Bormann, A.; Großmann, H., 2004. "The Impact of ACP/EU Economic Partnership Agreements on ECOWAS Countries: An Empirical Analysis of the Trade and Budget Effects”, prepared for Friedrich-Ebert-Stiftung by the Hamburg Institute of International Economics, July. 
CDD, 2002. "From Regional Security to Regional Integration in West Africa: Lessons from the ASEAN Experience”, Centre for Democracy \& Development Working Paper No. 5, June.

Chomba, F.M., 1990. "Integration of Africa through treaties", in Integration of African Continent through Law, Federal Ministry of Justice Law Review Series, Vol. 7, Nigeria.

Claeys, A.; Sindzingre, A., 2003. "Regional Integration as a Transfer of Rules: The Case of the Relationship Between the European Union and the West African Economic and Monetary Union (WAEMU)”, Paper presented at the Development Studies Association Annual Conference, Glasgow, September.

Delvaux, E., (2001/2) “The Challenge of the Informal Economy”, The Challenge of Globalization in Africa: The trade union response, Workers’ Activities Labour Education 2001/2 No. 123, ILO, Geneva.

ECA, 2004. Assessing Regional Integration in Africa. Addis Ababa, United Nations Economic Commission for Africa.

ECOWAS, 1975. Treaty of the Economic Community of West African States.

, 1979. Protocol A/P.1/5/79 Relating to Free Movement of Persons, Residence and Establishment.

1985. Supplementary Protocol A/SP.1/7/85 on the Code of Conduct for the Implementation of the Protocol on Free Movement of Persons, the Right of Residence and Establishment.

1986a. Supplementary Protocol A/SP.1/7/86 on the Second Phase (Right of Residence) of the Protocol on Free Movement of Persons, the Right of Residence and Establishment.

1986b. Decision A/DEC.2/7/86 Relating to the Creation of the Organization of Trade Unions of West Africa, the Adoption of the Check-off System and Meetings of ECOWAS Ministers of Labour. Abuja, July.

, 1989. Supplementary Protocol A/SP.1/6/89 Amending and Complementing the Provisions of Article 7 of the Protocol on Free Movement, Right of Residence and Establishment.

, 1990. Supplementary Protocol A/SP.2/5/90 on the Implementation of the Third Phase (Right of Establishment) of the Protocol on Free Movement of Persons, Right of Residence and Establishment.

1991a. "Declaration A/DCL.1/91 of Political Principles of the Economic Community of West African States", from the Fourteenth Session of the Authority of Heads of State and Government, Abuja, July.

, 1991b. Protocol A/P.1/7/91 on the Community Court of Justice. ECOWAS, Abuja, July.

, 1993a. Treaty of ECOWAS.

, 1993b. General Convention on Social Security between the Member States of the Economic Community of West African States. Lagos, May.

1994. Decision A/DEC.9/8/94 Establishing Regulations for the Granting to Non-Governmental Organizations (NGO's) the Status of Observer Within the Institutions of the Economic Community of West African States. 
1996. Regulation C/REG.5/11/96 Establishing a Forum of Associations Recognized by ECOWAS (FARE).

2000a. Meeting of ECOWAS Ministers of Trade on Post-Seattle: Note on Post-Seattle Challenges. Bamako, 29 January.

— 2000b. "Implementation and Follow-Up of the Dakar Declaration”, West African Regional Ministerial Meeting on the Participation of Migrants in the Development of their Country of Origin, Dakar, October.

, 2001a. "Civil Society Crucial to True Integration, Says ECOWAS Executive Secretary”, ECOWAS Press Release No. 48, 10 May.

, 2001b. Protocol A/SP1/12/01 on Democracy and Good Governance - Supplementary to the Protocol Relating to the Mechanism for Conflict Prevention Management, Resolution, Peacekeeping and Security. Dakar, December.

— 2002a. "Experts Meet to Adopt ECOWAS Policy on Gender Mainstreaming”, ECOWAS Press Release No. 11, 21 March.

— 2002b. "Experts Recommend Special Department for Gender Issues”, ECOWAS Press Release No. 24, 16 April.

, 2002c. The Rules of the Community Court of Justice. ECOWAS, Abuja, June.

, 2002d. "ECOWAS, Migration Organization Sign Cooperation Agreement”, ECOWAS Press Release No. 60, 31 July.

, 2002e. "Fostering Regional Integration Through NEPAD Implementation”, Annual Report 2002 of the Executive Secretary, ECW/CM/XLIX/2, Abuja, December.

—_, 2002f. ECOWAS Community Court of Justice - 2002 Annual Report. ECOWAS, Abuja.

— 2003a. ECOWAS Community Court of Justice - 2003 Annual Report. ECOWAS, Abuja.

— 2003b. Decision A/DEC.16/01.03 Relating to the Transformation of the West African Women Association (WAWA) into the ECOWAS Gender Development Centre. Twenty-Sixth Summit of the Heads of State and Government, Dakar, January.

, 2003c. "Strengthening Human Security capacities of ECOWAS and West African civil societies”, Notes from the first ad hoc committee meeting, Abuja, October.

2003d. Formulation of Regional PRSP. Fifty-first session of the Council of Ministers, Information note from the Executive Secretariat, ECOWAS, Accra, December.

—, 2004a. "ECOWAS Moves Ahead with NEPAD Project Implementation”, ECOWAS Press Release No. 10, 20 February.

, 2004b. ECOWAS Gender Policy Final Draft. ECOWAS, Abuja, March.

—_, 2004c. ECOWAS Gender Policy - Annex 1. ECOWAS, Abuja, March.

—

— 2004e. Final Report - First Meeting of the Human Resources, Information, Social and Cultural Affairs Commission. Abuja, March. 
2004f. "ECOWAS UEMOA Sign Cooperation Agreement for Regional Integration", ECOWAS Press Release No. 37, 6 May.

, 2004g. "ECOWAS Ministers of Trade Adopt Road Map for Economic Partnership Agreement with the European Union”, ECOWAS Press Release No. 61, 4 August.

Egulu, L., 2004. "Trade Union Participation in the PRSP Process”, Social Protection Discussion Paper No. 0417, World Bank, Washington, D.C., August.

Emeka Okolo, J., 1990. “ECOWAS Regional Cooperation Regime”, German Yearbook of International Law, vol. 32, pp. 1-137.

Friedrich-Ebert-Stiftung, 2004. Rapport general de l'atelier regional sur la participation des acteurs non étatiques en Afrique de l'ouest au processus de dialogues et de consultations dans le cadre de l'accord ACP-UE de Cotonou: Le cas du processus de revue. Friedrich-Ebert-Stiftung, Cotonou, May.

Godfrey, K., 2002. “Critique of the New Partnership for Africa’s Development (NEPAD)”, Zimbabwe Congress of Trade Unions. On file with author.

Godinho Gomes, P.A., 2001. “UEMOA: Promoting Integration Through Dialogue”, ILO Africa, No. 11 semester 2, p. 9.

ICFTU, 2002. Regional Conference on the Challenge of Globalization in Africa: The Role of Trade Unions in Promoting Balanced Development: Programme of Action. ICFTU-AFRO, Nairobi, May.

ILO, 2002. Social dimension of globalization and integration processes. IACLM-ILO Project, Working Paper No. 146, ILO Regional Office for the Americas, Lima.

— 2003a. The labour dimension within regional integration and free trade agreements in the Americas. Project "Principles and Rights at Work in the context of the XII Inter-American Conference on Ministers of Labour - OAS”, ILO Regional Office for the Americas, Lima.

, 2003b. "Regional Integration and International Cooperation in the ECOWAS: The Role of Employers’ Organizations”, ILO Employers’ Activities Sub-regional Workshop, Ouagadougou, February.

—, 2003c. ILO activities in Africa, 2000-2003, Report of the Director-General, Tenth African Regional Meeting, Addis Ababa, December.

, 2003d. Decent work for Africa's development, Report of the Director-General, Tenth African Regional Meeting, Addis Ababa, December.

—_, 2003e. Projet migration de main-d'oeuvre et développement en Afrique de l'ouest”, Rapport général du symposium tripartite sous-régional du BIT sur la migration de main-d'oeuvre et le développement en Afrique de l'ouest, Dakar, December.

— 2003f. Review of annual reports under the follow-up to the ILO Declaration on Fundamental Principles and Rights at Work, Governing Body, GB.286/4.

, 2004a. A Fair Globalization: Creating opportunities for all. Report of the World Commission on the Social Dimension of Globalization. Geneva. 
— 2004b. A Fair Globalization: The Role of the ILO, Report of the Director-General on the World Commission on the Social Dimension of Globalization, International Labour Conference, $92^{\text {nd }}$ Session, Geneva.

IOM, 2004. Migration Initiatives 2004, International Organization for Migration, Geneva.

IRIN, 2004. "Côte d'Ivoire: New labour law is not exclusionary - minister", UN Office for the Coordination of Humanitarian Affairs, 16 August.

Johansen, H.; Buckley, G., 2004. "Decent Work and the PRSP Process in West and Central Africa - An ILO Status Report”, unpublished paper, on file with author.

Langhammer, R.J.; Hiemenz, U., 1990. Regional Integration Among Developing Countries: Opportunities, Obstacles and Options. Kieler Studien 232, Institut für Weltwirtschaft an der Universität Kiel, Tübingen.

Lavergne, R. (ed.), 1997. Regional Integration and Cooperation in West Africa: A Multidimensional Perspective. International Development Research Centre, Ottawa.

Lyakurwa, William M. et al., 1997. "Regional Integration in Southern Africa: A Review of Experiences and Issues”, in Oyejide, A. et al. (eds.), Regional Integration and Trade Liberalization in Subsaharan Africa: Framework, Issues and Methodological Perspectives, vol.1, New York.

Malenzapa, A.K., 2003. "Etude de faisabilité pour la création d'une structure tripartite de dialogue social au sein de la communauté économique et monétaire de l'Afrique centrale” ILOPRODIAF, Bangui, June.

Manboah-Rockson, J.K., 2000. "Regionalism and Integration in Sub-Saharan Africa: A Review of Experiences, Issues and Realities at the Close of the Twentieth Century", in Innovations: A Journal of Politics, vol. 3, pp. 47-68.

Martìnez, D., 2004. "The World of Work in the Context of Economic Integration and Trade Liberalization: From the vantage point of the Americas", ILO Policy Integration Department, Working Paper No. 45, Geneva.

Mlimuka, A., 2003. "Labour Law, Its Reform and Harmonisation in East Africa: Implications for Employers”, Presentation made at ILO/SLAREA Sub-Regional Workshop for Employers on Competitiveness and Productivity - The Human Dimension, Kampala, April.

Mndeme Musonda, F., 2004. "The Implications to Tanzania of the East African Community Protocol and Free Movement of Persons and Services and the Right to Establish Residence: The future role of the government associations of employers (ATE) and the trade unions", Unpublished paper, April.

Mwamadzingo, M., 2001/2. "Regional Integration in Africa: Getting it Right”, The Challenge of Globalization in Africa: The trade union response, in Labour Education 2001/2 No. 123, ILO, Geneva.

Ndongko, W.A., 1991. "Labour migration and regional economic cooperation and integration in Africa”, in Labour and Society 16/3.

Ninalowo, A., 2003. "Democratic Governance, Regional Integration and Development in Africa”, Development Policy Management Forum Occasional Paper No. 11, Addis Ababa.

OAU, 1981. African [Banjul] Charter on Human and Peoples' Rights. 


\section{—_ 1991. Treaty Establishing the African Economic Community.}

OECD, 1993. Intégration régionale et pays en développement. OECD, Paris.

Oteng Kufuor, K., 1994. "Law, Power, Politics and Economics: Critical Issues Arising out of the New ECOWAS Treaty”, in African Journal of International Comparative Law, vol. 6, pp. 429448.

1996. "Securing Compliance with the Judgments of the ECOWAS Court of Justice”, in African Journal of International Comparative Law, vol. 8, pt. 1, pp. 1-11, March.

— 2000. "Public Choice Theory and the Failure of the ECOWAS Trade Liberalization Scheme", 23 World Competition: Law and Economics Review 4, pp. 137-154.

Ovrawah, A.O., 1994. "Harmonisation of laws within the ECOWAS”, African Journal of International and Comparative Law, 6 RADIC 76-92.

Page, S; Bilal, S, 2001. "Regional Integration in Western Africa”, Report prepared for and financed by the Ministry of Foreign Affairs, the Netherlands, Overseas Development Institute, September.

PANA, 2004. "Women Ministers Call for Gender Policy in ECOWAS”, Panafrican News Agency, 21 February.

PricewaterhouseCoopers, 2004. "Sustainability Impact Assessment (SIA) of the EU-ACP Economic Partnership Agreements - Regional SIA: West African ACP countries”, Institut de Prospective Africaine.

Reynaud, A.C., 2001. Labour Standards and the Integration Process in the Americas. International Labour Organization, Geneva.

Salam Fall, A., 2003. "Enjeux et défis de la migration internationale de travail ouest-africaine”, ILO International Migration Paper No. IMP 62F, Geneva.

Schiff, M. and Winters, L.A., 2003. Regional integration and development. World Bank, Washington, D.C.

Söderbaum, F., 1996. Handbook of Regional Organizations in Africa, Nordiska Afrikainstitutet, Uppsala.

Thompson, B., 1990. "Legal Problems of economic integration in the West African sub-region", African Journal of International and Comparative Law, 2 RADIC 85-102.

Udombana, N.J., 2002. "Can the Leopard Change Its Spots? The African Union Treaty and Human Rights”, 17 American University International Law Review. 1177.

UNCTAD, 1996. "Regional and Subregional Economic Integration Groupings", Handbook of Economic Integration and Cooperation Groupings of Developing Countries, vol. 1, United Nations Conference on Trade and Development, Geneva.

UNCTAD, 2004. The Least Developed Countries Report 2004: Linking international trade with poverty reduction. United Nations Conference on Trade and Development, Geneva. 
USTR, 2004. 2004 Comprehensive Report on U.S. Trade and Investment Policy Toward Sub-Saharan Africa and Implementation of the African Growth and Opportunity Act. United States Trade Representative, Washington, D.C.

van Liemt, G., 1999. “Globalization and labour issues - an international perspective”, in W. Momm (ed.), Labour issues in the context of economic integration and free trade, ILO Subregional Office for the Caribbean, Port of Spain.

WACSOF, 2003a. Communiqué of the West African Civil Society Forum, WACSOF, Accra, December.

— $2003 b$. Draft Charter of the West African Civil Society Forum, WACSOF, Accra, December.

—

Walgrave, J., 2001. “Social Dialogue in Africa, A Reality”, in ILO Africa, No. 11 semester 2, pp. 1-3.

World Bank, 2000. "World Bank Supports Regional Integration in West Africa”, World BankNews Release No. 2001/098/AFR.

—_ 2001. "Memorandum of the President of the International Development Association to the Executive Directors on a Regional Integration Assistance Strategy for West Africa”, World Bank, online: http://www-

wds.worldbank.org/servlet/WDSContentServer/WDSP/IB/2001/07/27/000094946_01071704015882 /Rendered/PDF/multi0page.pdf

, 2004. "ECOWAS Leaders, World Bank Head Push Regional Approaches on Trade, Infrastructure and Peace”, World Bank News Release No. 2004/280/AFR. 


\section{Policy Integration Department Working Papers}

No. 1 ILO activities on the social dimension of globalization: Synthesis report

No. 2 Measuring decent work with statistical indicators, Richard Anker, Igor Chernyshev, Philippe Egger, Farhad Mehran and Joseph Ritter

No. 3 Globalization and decent work: Options for Panama Philippe Egger

No. 4 Globalización y trabajo decente: Opciones para Panamá, Philippe Egger

No. 5 Indicators of social dialogue: Concepts and measurements, Lane Kenworthy and Bernhard Kittel

No. 6 Assessing the impact of the attacks of 11 September 2001 on women's employment in the United States, Gertrude Schaffner Goldberg and Helen Lachs Ginsburg

No. 7 Decent work and the informal economy in Central America, Juan Diego Trejos Solórzano and Miguel Del Cid

No. 8 Poverty initiatives in the ILO: A review of past and present approaches, Pat Holden and Dagmar Walter

No. 9 Whither the International Standard Classification of Occupations (ISCO-88)?, Debbie Budlender

No. 10 Improving occupational classifications as tools for describing labour markets: A summary of recent national experiences, Debbie Budlender

No. 11 Recent developments in China's labour economy, Thomas G. Rawski

No. 12 The Impact of economic liberalization on employment and wages in India, Sonia Bhalotra

No. 13 The impact of trade liberalization upon inequality in developing countries, Donald J. Robbins

No. 14 The impact of liberalization and globalization on income inequality in developing and transitional economies, Giovanni Andrea Cornia

No. 15 The impact of technology transfer on employment and income distribution in developing countries: A survey of theoretical models and empirical studies, Mariacristina Piva 


\section{Policy Integration Department Working Papers prepared for the World Commission on the Social Dimension of Globalization}

No. 16 International finance: Meeting the needs of people in developing countries, José Guilherme Almeida dos Reis

No. 17 The gender dimensions of globalization of production, Stephanie Barrientos, Naila Kabeer and Naomi Hossain

No. 18 Social exclusion in the context of globalization, Jan Breman

No. 19 Gender and globalization: A macroeconomic perspective, Çağatay Nilüfer and Ertük Korkurt

No. 20 Globalization, social exclusion, and work: with special reference to informal employment and gender, Marilyn Carr and Martha Chen

No. 21 Resources for social development, Antony Clunies Ross

No. 22 Does the new international trade regime leave room for industrialization policies in the middle-income countries?, Alisa DiCaprio and Alice Amsden

No. 23 Social dimension of globalization in Latin America: Lessons from Bolivia and Chile, Alvaro García Hurtado

No. 24 The social dimension of globalization: a review of the literature, Bernhard Gunter and Rolph van der Hoeven

No. 25 The social dimension of global production systems: A review of the issues Susan Hayter

No. 26 Reforming global economic and social governance:

a critical review of recent programmatic thinking, Jeremy Heimans

No. 27 Corporate social responsibility: an issues paper, Michael Hopkins

No. 28 Upgrading in global value chains, John Humphrey

No. 29 Implications of globalization and economic restructuring for skills development in Sub-Saharan Africa, Richard K. Johanson

No. 30 The outcome and impact of the main international commissions on development issues, Frédéric Lapeyre

No. 31 Globalization and structural adjustment as a development tool, Frédéric Lapeyre

No. 32 Globalization and perceptions of social inequality, Malte Luebker

No. 33 The changing structure of international trade linked to global production systems: what are the policy implications?, William Milberg

No. 34 Corporate social responsibility: an overview of principles and practice, Jill Murray

No. 35 Inclusive development strategy in an era of globalization, Ignacy Sachs

No. 36 Social consequences of the globalization of the media and communication sector: some strategic considerations, Seán Ó. Siochrú

No. 37 Globalization, history and international migration: a view from Latin America, Andrés Solimano

No. 38 Towards a different kind of globalization, or how the anti-globalists view the world, Gijsbert van Liemt 


\section{Policy Integration Department Working Papers}

No. 39 How do trade union rights affect trade competitiveness? David Kucera and Ritash Sarna

No. 40 Statistics on the employment situation of people with disabilities: A compendium of national methodologies

ILO Bureau of Statistics in collaboration with the In Focus Programme on Skills, Knowledge and Employability

No. 41 Employment in the informal economy in the Republic of Moldova ILO Bureau of Statistics in collaboration with the Department for Statistics and Sociology of the Republic of Moldova

No. 42 Decent work in a least developed country: A critical assessment of the Ethiopia PRSP, Graeme J. Buckley

No. 43 Unemployment and Labour Market Institutions: The Failure of the Empirical Case for Deregulation, Dean Baker, Andrew Glyn, David Howell and John Schmitt

No. 44 Women's access to occupations with authority, influence and decision-making power: Women as legislators, senior officials and managers around the world, Richard Anker

No. 45 The world of work in the context of economic integration and trade liberalization, Daniel Martínez

No. 46 Poverty reduction in Pakistan: The strategic impact of macro and employment policies, Moazam Mahmood

No. 47 Trends in Work Stoppages: A Global Perspective, L. J. Perry and Patrick J. Wilson

No. 48 Generating decent work for poverty reduction in Cambodia: The voice of workers, employers and the Government; Moazam Mahmood

No. 49 The Social Dimension of Regional Integration in ECOWAS, René Robert 